\title{
PRATICA FORENSE
}

Ireges in Scholis deglutiuntur et in Palatio digeruntur, quia pratica est digestiva, et ubi theoricus definit, praticus incipit.

(Mendes de Castro, Prat. Lusit., II, proem.)

\section{DR. JOAOO MENDES DE ALMEIDA JUNIOR.}


Sed cum legebat, oculi ducebantur per paginas, et cor intellectum rimabatur. rox autem et lingua quiescebant.

(Sto. Acostinfo, Confiss., L. VI, III, 2)

Quando lia, seus olhos caminhavam pelas paginas, seu espirito penetrava nellas, sua voz, porem, e sua lingua descançavam.

Sed fortasse proprie diceretur, tempora sunt tria: preseus de preteritis, preseus de presentibus, preseus de futuris. Sunt enim haec in anima tua quaedam, et alibi ea non video. Preseus de preteritis, memoria; preseus de presentibus contruituos; preseus de futuris, expectatio.

(S. Áost. Conj., IX, 20). 


\section{TITULO I}

\section{Natureza e objecto da Pratica Forense.}

\section{CAPITULO I}

SUMMARIO - Relações entre a theoria e a pratica. - Relações entre a sciencia, a prudencia e a arte.

A faculdade de conhecer tem duas modalidades: ou se limita á contemplação da verdade, sem destinar á operação o objecto conhecido; ou raciocina com o fim de proceder a uma operação. A primeira modalidade toma o nome de intellecto especulativo; a segunda toma o nome de intellecto pratico (1)

O intellecto pratico, applicando os principios geraes ás operações, forma juizos particulares para decidir si convem fazer tal cousa ou se tal cousa deve ser feita desta ou daquella forma, e esses juizos previos do intellecto pratico versam sobre factos contingentes e determinam o acto da vontade;

O intellecto especulativo contempla principios e phenomenos para deduzir conclusões e induzir leis, cuja applicação não depende de nosso poder ou não está em nossa intenção, o intellecto pratico contempla principios e phe-

(1) Aristoteles, de anima, III, cap. IX, de motu animalium, text, 10, n. 2. Devemos observar que citando o Philosepho, nos referiremos sempre as traducções latinas, cujos textos serviram para os commentarios dos escolasticos.

KANT chegou a affirmar que estas duas manifestações não são modalidades de uma mesma potencia, mas faculdades ou potencias especificadamente differentes, ás quaes deu o nome de razão pura e razão pratica. Os escolasticos porem mantiveram, com a maioria dos philosophos, a doutrina de Aristuriles; continuaram a sustcnlar que o intellecto pratico é uma extensão do intellecto respeculativo. 
nomenos para deduzir conclusões e induzir leis cuja applicação depende da nossa actividade livre e está em nossa intenção.

A operação humana, objecto do intellecto pratico, realisa-se por dois modos: por acção immanente e por acção transitiva. $O$ verbo agir exprime a acção immanente; o verbo fazer exprime a acção transitiva (1). Agir é realizar uma operação que não passa do proprio agente e consiste no proprio acto: por exemplo, pensar, julgar, raciocinar, estudar, etc. Fazer é realizar uma operaçäo que passa para a materia externa, operação cujo effeito distingue-se do proprio acto por exemplo, fallar, escrever, encadernar, etc. A palavra-pratica-deriva-se da raiz grega, pratlein, que significa fazer; e, assim, é mais propriamente empregada para exprimir a acção transitiva.

Ora, a acção transitiva, praticada pelo homem em seu estado normal, é sempre precedida da escolha ou eleição dos meios, esta eleição é um acto do appettite previamente illuminado pela razão, e, portanto presuppõe a consulta ou raciocinio do intellecto pratico. Depois de achados os meios, depois de contemplada a verdade dos principios geradores desses meios, depois de verificada a aptidão desses meios para a consecução do fim do agente, - somente, então, é que o agente voluntariamente inicia o processo ou a. marcha da operação (2).

$\mathrm{O}$ intellecto pratico e o intellecto especulativo não constituem faculdades especificamente differentes, o intellecto pratico é uma certa extensão do intellecto especulativo, ou antes é a mesma faculdade de conhecer applicada a. uma obra particular (3)

(1) Actio et factio, segundo os termos da Escola. Actio significa a acção. immanente; factio, a aç̧ão transitiva.

(2) Anistot., de communi animalicum motione, cap. IV, text, 7, n. 2. udi, text, 7, n. 2 .

(3) Idem, text. cit e respectivo commentario de Mauro, tomo IV, pag. 203. 
Em taes condições depois que o intellecto especulativo contempla a verdade dos principios, dos phenomenos. das conclusões ou das leis, o intellecto pratico passa a contemplar a verdade das calltelas.

Ora, a palavra-theoria-deriva-se da raiz grega, teoros, que significa-contemplar; e esta necessidade de contemplar apparece tanto na ordem especulativa como na ordem pratica. Não ha, pois, incompatibilidade possivel entre a theoria e a pratica; ao contrario, uma theoria que não é praticavel, ou é falsa, ou, pelo menos, é incompleta. Por isso se diz que a comparação com a experiencia é a pedra de toque de toda a theoria. (1)

O direito, sobretudo, exige a mais rigorosa realisabilidade. "O direito, diz voN IHERING (Espirito do Direito Romano, I, pag. 16, e III, pag. 51), existe para ser realisado... Eu distingo a realisabilidade material da realisabilidade formal do direito... A primeira consiste na utilidade ou opportunidade das disposições do fundo do direito. A segunda consiste na facilidade e segurança da applicação do direito abstracto ás especies concretas." A applicação do direito ao facto não póde ser feita sem o previo conhecimento da $l e i$; e a lei, nunca devendo affastar-se da verdade juridica, pertence a theoria do direito. $\mathrm{O}$ raciocinio que o intellecto pratico forma para applicar a lei ao facto, consiste em um syllogismo cuja premissa maior é o principio geral ou a lei, cuja premissa menor é o facto, e cuja conclusão é a adequação da lei ao facto.

Exemplifiquemos: a escriptura publica é da substancia da compra e venda de bens de raiz, cujo valôr exceder de um conto de reis (premissa maior, que é o principio geral contido no art. 134, II, do Codigo Civil), ora, Pedro

(1) Inering, Esp. do D. R. I. 50, exprime estas relações entre a theoria e a pratica do Direito pela seguinte brilhante metaphora. " $O$ direito, tal como se nos mostra em suas formulas legislativas, é semelhante ao plano de uma machina; a melhor explicação, e critica, ao mesmo tempo nos são offerecidas pela propria machina, quando funcciona; então, mais de uma mola, a principio despercebidas revelam sua profunda importancia, - e mais de uma roldana, muito salientes, muito necessarias na apparencia, manifestam sua superfluidade. 
comprou a Paulo, o predio tal por valôr excedente a um conto de reis (premissa menor, que é o facto), logo, Pedro e Paulo, para darem substancia a essa compra e venda, devem fazel-a por escriptura publica (conclusão, que é 0 juizo particular, applicando o direito ao facto)

Os Estatutos da Universidade de Coimbra, L. II, Tit. VI, cap. VIII, ns. 3 e 7, assim se exprimem. "A applicação das leis é um juizo pratico de que o caso, ou a acção, se deve decidir pela lei, que tem determinações communs com elle... A applicação das leis se faz mediante um discurso ou raciocinio, no qual a determinação adequada e completa da lei, deve formar a premissa maior e distribuir-se na menor, introduzindo-se nesta a acção ou caso da lei, e ficando servindo de sujeito, do qual se affirma a mesma determinação da lei como predicado, para isso é necessario ter bem presentes as determinações sobreditas da lei $e$ do facto com todas as suas respectivas circunstancias, e combinal-as $e$ pezal-as em uma exacta balança; tudo isso requer um juizo prudente, sagaz, maduro e circunspecto."

As operações tendentes a assegurar e facilitar a realisação do direito na vida são transitivas, passam para a materia externa, geram um producto distincto da propria operação. Ora, as operações desta natureza, resultando movimento dos orgãos no tempo e no espaço, não dependem somente da sciencia, dependem principalmente da arte. Ha mesmo uma derivação etymologica entre a palavra portugueza-arte-e o substantivo latino-artus -, que significa. - articulações dos membros - e que, entre os classicos, foi empregado para significar os proprios membros do: organismo animal.

Mas, o movimento artistico caracterisa-se por uma dupla operação: uma, que se chama intelligencia e que constitue a ordem da intenção; outra, que se chama effectuação e que constitue a ordem da execução. O artista póde, pelo simples conhecimento das regras de sua arte e pelo habito de executal-a, produzir uma obra perfeita, segundo o plario 
dado por outros, si, porem, tiver de seguir a propria intenção, deve o artista, antes de proceder á effectuação, excogitar um plano, meditar sobre esse plano e tomar, para seguránça da execução, as cautelas indicadàs pela prudencia. (1) Se assim è nas artes mechanicas, com maioria de razão deverá acontecer o mesmo nas artes liberaes. Na execução de uma obra darte mechanica, o artista não tem em vista o bem moral e sim o bem da obra em si, isto é, a perfeição do artefacto; na execução de uma obra darte liberal, como é a arte forense, o artista póde, mas não deve prescindir do bem moral.

A arte, por sua essencia, não presuppõe uma vontade recta; comtudo, a arte liberal, por sua dignidade e excellencia, não deve prescindir da vontade recta ou moralidade do agente. A prudencia, que produz essa vontade recta, ligase, pois, á arte, non essentialiter sed ad modum dispositionis, como dizem os escolasticos, e mais habil será o artista, si, ás cautelas da prudencia, juntar as conclusões da sciencia. E' esta a razão pela qual os citados Estatutos da Universidade de Coimbra, exigem, para a arte de applicar as leis aos factos, "um juizo prudente, sagaz, maduro e circunspecto"

(1) Os escolasticos distinguem com o Philosopho, alem da sabedoria e da intuição dos primeiros principios, tres outras virtudes intellectuaes, que são a sciencia, a prudencia e a arte. A sabedoria, a intuiçũo dos principios e a sciencia - são habitos intellectuaes especulativos; a prudencia e a arte são habitos intellectuaes praticos. Entre estes dous habitos praticos, ha relaçóes intimas e as seguintes differenças: a prudencia versa sobre as acções immanentes, ao passo que a arte, versa sobre as acções transitivas; a prudencia tem principalmente em vista o fim operante, o bonum operantis, ao passo que a arte tem principalmente em vista o fim da obra, o bonum operati. A prudencia define-se um habitus cum recta ratione activus; a arte define-se um habitus cum vera ratione factivus. (Vide a cit. Mavro, comm. aos text. 4 e 5 da Ethica a Nicomacho, tom. II, pag. 155 e segs.). 


\section{CAPITULO II}

SUMmARIo - Pratica doutrinal, pratica legislativa, pratica forense. Jurisprudencia pratica: enrematica e formularia.

O direito deve ser demonstrado, deve ser transformado em leis e deve ser applicado aos factos.

I - As regras juridicas podem ser consequencias de principios geraes e podem resultar da observação dos phenomenos ou relações da vida social. Regula est quae rem, quae est, breviter enarrat; non ut ex regula jus summatur, sed exjure, quod est, regula fiat. (DIG., de reg. juris, fr. 1 de PAUlo) Estas regras, resultantes dos principios e dos factos, traduzem relações que se agrupam em unidades systematicas, denominadas - instituições de direito. Deste modo, pela deducção e pela inducção, depois pela analyse e pela synthese, o direito eleva-se á cathegoria de sciencia.

$\mathrm{O}$ direito, assim considerado, tem uma entidade distincta da sua applicação. Não devemos, pois, aceitar, como absoluta, a seguinte proposição do citado VON IHERING $(I, 50)$ "O que não se realisa não é direito" Esta proposição deve ser entendida por esta outra do mesmo vON IHERING $(I I I, 16)$ "O direito existe para ser realisado", ou antes, deve ser entendida conforme a seguinte phrase de Savigny, Systema do Direito Romano $(\mathrm{I}, 36)$ "A applicação do direito é o signal de sua existencia" O direito, como regra scientifica, tem entidade, ainda mesmo que não passe do estado de possibilidade para o estado de existencia ou actualidade, ainda mesmo que não se realise hic et nunc. A theoria scientifico-juridica deve ser realisavel, mas pode ser realisada; nem por isso, deve deixar de ser ensinada e estudada, ainda que, da parte do professor e do interprete, não haja 0 intento de applicar a doutrina. 
A doutrina, considerada como o acto do ensino, requer: 1) a sciencia do jurisconsulto ou do professor, sciencia que deve consistir no habito da demonstração; 2) o talento da communicação ou o methodo. Este ultimo requisito, resultado da prudencia nos meios de despertar a attenção e da arte de expôr com clareza, constitue o predicado da pratica doutrinal.

II - Entretanto, o direito existe para ser realisado. Não basta a verdade das regras, é necessario ainda a sua realisabilidade. $\mathrm{O}$ homem da sciencia contempla principalmente a verdade juridica, sem desconhecer que esta verdade deve ser realisavel; o homem da lei busca os meios de transformar as regras em preceitos, tendo em vista principalmente a realisabilidade. O legislador, confeccionando preceitos relativos á materia e á forma das relações de direito, tem a tarefa toda relativa ás condições peculiares da vida de um povo. Essa tarefa exige dous predicados. o dom de observação e o talento da redacção, dos quaes o primeiro caracterisa a prudencia, o segundo a arte do legislador, e ambos caracterisam a pratica legislativa (1) Já Cicero, de officis (III, 17), assim se manifestava: Aliter leges, aliter philosophi tollunt astutias; leges, quatenus manu tenere possunt, philosophi, quatenus ratione et intelligentia.

III - Confeccionadas e promulgadas as leis, resta applical-as aos casos particulares. Assegurar e facilitar a applicação das leis aos factos - é a tarefa da pratica forense. Essa tarefa depende das cautelas da prudencia e das regras da arte de formalizar a vontade juridica. (2)

- A pratica forense é tambem chamada jurisprudencia pratica. Convem agora fixar as noções.

I - Distingue-se a jurisprudencia pratica cia jurisprudencia theorica no seguinte: 1) A jurisprudencia theo-

(1) O sabio CarraRa não duvidou aconselhar a creação, nas Faculdades Jaridicas da Italia, de uma cadeira de Pratica Legislativa (Carrara, part. Legis. lativa Penal, pag. 8).

(2) Cit. Estat. da Univ. de Coimbra, L. II, tit. VI. cap. III, n. 51: 
rica estabelece os principios geraes, observa as relações: sociaes, demonstra as regras, organiza as instituições de direito, commenta as leis e faz a critica da applicação destas aos factos passados, a jurisprudencia pratica, acautela-se com a memoria desses subsidios e estabelece a forma externa para os casos concretos que se apresentarem na scena juridica. 2) A jurisprudencia theorica fornece a especie ou forma intrinseca do acto e as leis respectivas; a jurisprudencia pratica, aproveitando o acto assim determinado por sua forma intrinseca e as leis respectivas, dá ao mesmo acto uma forma extrinseca. Em resumo a jurisprudencia theorica demonstra e critica a jurisprudencia pratica consulta e formúla. A jurtsprudencia theorica abrange a sciencia juridica, a legislação e a critica dos casos consummados e julgados, ao passo que a jurisprudencia pratica, abrange as cautelas e as formulas para os casos presentes e futuros. Dahi decorre a divisão da jurisprudencia pratica em dois ramos: a jurisprudencia cautelaria (technicamente chamada jurisprudencia eurematica), e a jurisprudencia formularia.

II - A jurisprudencia eurematica ensina as cautelas destinadas a manter a regularidade e evitar a nullidade dos actos juridicos. Eurema é uma palavra grega que significa cautela, precaução, prevenção.

A jurisprudencia eurematica toma cautelas relativas á capacidade dos agentes juridicos, ao objecto do direito, ao modo de declarar a intenção e a vontade, e mesmo relativas aos requisitos da forma externa. Estas cautelas são dictadas pela prudencia, que consiste na rememoração das leis (1), na observação attenta dos factos $e$ de todas as

(1) BACon, De dignitate et augmentis Scienciarum, no aphorismo LXXXVII. diz: Practica vero plurimum interest, ut jus universum digeratur ordine, in locus et titulos, ad quos subito (prout dabitur occasio) recurrere quis possit, veluti in. promptuarium paratum ad presentes usus...Hujus modi libri summarum, et ordinant sparsa et abbreviant fusa et prolixa in lege. Cavendun autem est ne summae istae. reddant homines promptos ad practicam cessatores in sciencia ipsa Earum enim. officium est tale ut ex iis recolatur jus, non perdicatur. Summae autem amnimo, magna deligencia, fide et judicio, sunt conficienda, ne fartum faciant legibus. 
suas circunstancias (2), na experiencia (3), na perspi-
cacia (4), na sagacidade (5), na previdencia (6),
na circunspecção (7), na docilidade (8), na pacien-

"Para a pratica muito importa que todo o direito seja ordenadamente disposto em logares e titulos, aos quaes, logo que se lhe dê occasião, se possa recorrer cono a um promptuario preparado para os usos presentes. Deste modo, os livros summarios coordenam as disposições esparsas e abreviam as disposições diffusas e prolixas da lei; é preciso, porem, ter muito cuidado com os summarios, afim de que as summas, tornando os homens promptos para a pratica, não os façam cessar na sciencia. Taes summarios tem por fim collecionar o direito já previamente sabido; não é por elles, portanto, que se apprende o direito; e, aliás, devem ser feitos com toda a diligencia, confiança e juizo, afim de que rememorem e não defraudem as leis".

(2) Attribue-se a um dos famosos jurisconsultos francezes do seculo XVI, Dumoulin, a insistencia em affirmar que "a menor differença no facto opera grandissima differença no direito" Modifica enim circunstancia facti inducit magnam juris diversitatem.

(3) Est. autem experiencia, per quam ex compatione plurium singularium, qurum recordamur, procedimus ad judicandum quid sit faciendum hic et nunc (Mauro, comm. ao text. 1 da Metaph. de Aristoteles, n. 4.).

(4.) Perspicaz é aquelle que, consultando, pode logo julgar do que deve fazer, ainda nas minimas circunstancias. Costuma-se tambem empregar a palavra perspicacia para significar a vivacidade do espirito, que consiste no habito de acertar no que convem fazer em um caso dado; mas a perspicacia refere-se mais a resolução, e a vivacidade de espirito á aç̧ão.

(5) A sagacidade, que consiste na descoberta rapida dos meios a empregar (AnIst, Post., I, 36), distingue-se da vivacidade de espirito como a especie se dislingue do genero.

(6) Cicero de invent., liv. II, e Macrabio, nos comm. a Sum. Scipionis (I, 8), fazem da previdencia uma das principaes partes da prudencix.

(7) A circunspecção tem por objecto o estudo attento e especial das circunstancias de um facto, ao passo que a previdencia versa sobre as relaçóes dos meios com o fim (Drioux, not. 2 ao art. VII da cit. quest. S. Thomaz de Aquino):

(8) A prudencia tem por objecto as acções particulares; e, como ella são innumeras, a vida do homem é curta para consideral-as todas. Dahi resulta a necessidade de sermos esclarecidos por outros e principalmente pelos velhos, que já formaram ideias são em relação a cousas praticas. A docilidade consiste em bem receber os ensinamntos dos outros. Aristoteles, na Ethica a Nicomacho (VII, II), diz que o homem prudente attende ás asserções e opinióes das pessoas idosas e cxperientes, ainda que taes asserçóes e opiniões não sejam logo demonstradas; pois, o golpe de vista da experiencia, suppóe, nos velhos e nos mestres, a necessidade de repetir os principios.

A imprudencia consiste na precipitação, na inconsideração, na inconslancia c na negligencia. I) A precipitação se diz metaphoricamente dos actos da alma por uma comparação ao movimento corporeo: assim, se diz que os movimentos do corpo são precipitados, quando vão de cima para baixo, seguindo a impetuosidade de scu movimento proprio ou impulso que receberam, sem passarem pelos graos intermediarios convenientes. Os graos intermediarios pelos quaes o espirito deve regularmente passar são: a memoria do passado, a intelligencia do presente, a sagacidade no presentimento do futuro. o raciocinio que compara uma cousa 
cia (1), na solicitude (2), na tenacidade e esperança de resultado (3)

As cautelas dividem-se em necessarias, legaes e uteis. (4) Cautelas necessarias são as que pronovem o commodo ou evitam o damno; cautelas legaes são as expressamente recommendadas pela lei; cautelas uteis, tambem chamadas cautelas abundantes, são aquellas que conquanto dispensaveis, não deixam de concorrer para maior segurança do direito. Entre as cautelas legaes, ha algumas que a lei recommenda com decreto irritante, isto é, sob pena de nullidade essas costumam ser denominadas cautelas de rigor.

Para evitar confusão de ideias, tornaremos salientes a distincção entre a jurisprudencia eurematica e a jurisprudencia theorica. Tanto esta como aquella consideram os elementos dos actos juridicos; mas a jurisprudencia theorica considera estes elementos quanto á essencia, e critíca a existencia delles em actos $j a ́$ exercidos - ao passo que a

a outra e a docilidade em submttter-se ao parecer dos antigos. Não passando e - espirito por todos estes gráos, da-se a precipitação. II) A inconsideração consiste na falta de attenção ás circumstancias particulares e variaveis dos factos. 1II) A inconstancia é a falta de firmeza em proseguir naquillo que foi julgado e proposto pela recta razáo. IV) A negligencia (de nec eligens, Livro das etym. $X$, tit. V), consiste na falta do acto interno da eleição dos meios; differe da preg̣iça e torpor por serem estes mais de execução do que de intenção, isto é, preguiça tarda a cxecutar e o torpor implica em certo relaxamento na execução.

(1) Patientia et gravitas, in causis audiendis, justitix e.t pars es entialis. (Appendice aos aphorismos de BAcon). A paciencia, diz Plinı, o Moşo, é uma grande parte da justiça. $\mathrm{O}$ grande Lionville, pondera que o interesse pessoal suscita quasi sempre expedientes, cautelas e contra-cautelas, que escapariam a perspicacia do mais sagaz, illustre e exercitados dos advogados; dahi decorre a necessidade que o advogado de ser paciente em ouvir o seu constituinte, ainda que lhe pareçam impertinentes.

(2) Diz o Philosopho (Eтнс. a Nicom., IV, 9), que se deve operar promptamente o que se resolveu, mas se deve ser lento em tomar a resolução. A solicitude (de solers, recto, e citus, rapido), conforme Santo Isidoro, Livio das Etymologias (X, ad litt. S), consiste na diligencia que nos leva a fazer prompta e rectamente o que resolvemos.

(3) A tenacidade e esperança do bom resultado são das principaes quar lidades da prudencia forense, principalmente em relação ao advogado. Emquanto houver recurso, nunca é licito desesperar; o bom advogado distingue-se pela invencivel constancia contra os mais poderosos obstaculos (Liouvile, Profession d'avocat, 97).

(4) Cit. Est., Lir. 11. tit. I1, cap. HI. n. 52. 
jurisprudencia eurematica considera esses elementos para dar-lhes existencia em actos a exercer Por isso diziam os Praxistas que a jurisprudencia theorica trata dos elementos dos actos juridicos como de actos de preterito, ao passo que a jurisprudencia eurematica trata desses elementos como de actos de futuro. (TEIXEIRA DE FREITAS, introd. ao Formulario do Tabellionato, pag. XXXIII)

A jurisprudencia eurematica divide-se em eurematica geral e eurematica particular A eurematica geral trata das cautelas relativas a toda e qualquer especie de acto juridico, a eurematica particular trata das cautelas relativas a uma certa e determinada especie de acto juridico, a um certo e determinado titulo de direito. Neste ultimo sentido se diz, por exemplo, a eurematica da compra e venda, a eurematica da hypotheca, a eurematica do processo criminal, etc.

III - A parte eminentemente artistica da pratica forense é a jurisprudencia formularia. Consiste ella na confecção da forma litteral dos actos juridicos. Essa forma litteral, quando confeccionada para exemplificar ou modelar os actos do fôro extrajudicial ou do fôro judicial, denomina-se formula forense. (1)

(1) Id. id., n. 55, ibi: "Porque ainda que as formulas, de que hoje se usa, não sejam aquellas formulas solemnes, perpetuas $e$ inalteraveis, de que usou a escrupulosa superstição dos antigos Romanos, nas quaes bastava a mudança ou a alteração de uma syllaba para fazer o acto nullo; ainda que, pelo contrario, as formulas, de que no presente e faz uso, admittam todas as mudanças e alteraçõos de palavras, que requerer a varidade de circunstancias e até a maior perfeição e pureza do estylo; e ainda tambem que, consequentemente, a respeito dellas se deva reprovar a tenaz adhesão e adstricção, que a cada clausula e ainda palavra della têm os tabelliães e advogados ignorantes, por não as entenderem, nem perceberem ljem a força e propriedade dellas; comtudo, sempre a noticia das formulas é muito conveniente e aproveitará muito aos ouvintes: 1) Porque como nellas se acha substanciada a natureza do negocio e de todos os requisitos delle, por ellas se consegue o conhecimento necesario da materia, com maior facilidade e promptidão; 2) Porque o exame das formulas contribue, para que mais se apure o juizo na comprehensão da jurisprudencia dos negocios; 3) Porque, por meio das formulas, se aprende o estylo do Fôro Civil e Judicial; 4) Porque a noticia das formulas facilita a expedição dos negocios, allivia muito a memoria, faz cessar o cuidado, que sempre ha, quando se celebram os negocios, e o receio, que depois delles celebrados póde ficar, de que por falta de lembrança se omittisse nelles algumas declarações, circunsiancia, ou clausula util e necessaria". 
Formulario forense é o complexo de formulas forenses, para serem applicadas com as modificações exigidas em cada caso particular. Os formularios são em geral, productos dos jurisconsultos e dos jurisperitos.

Ihering, referindo-se ao rigor formalista dos romanos, depois de compensar as vantagens e desvantagens desse formalismo, reconhece que as formulas das acções "forçavam o juiz a ser claro e, por outro lado, lhe impunham mechanicamente a imparcialidade" E, si no regimem das legis actiones, essas formulas eram obra dos ministros, dos deuses, dos pontifices, ha um facto que, comquanto sob um outro aspecto, se apresenta em todas as epochas posteriores, quer no regimem do processo formulario, quer no regimem do processo extraordinario, quer no regimem da completa abolição das formulas pelos imperadores Constancio e Valentinfano, quer no regimem das Leges Barburonn (1) "as formulas, ou se encontrem no Jus Flavianum, ou no Justinianum, ou no Album Proetoris, ou nas collecções de $M a$ rulfo, Baluze, Mabillon Goldast e outros são obra da Juris. prudencia, um producto artistico do espirito juridico" ISNERIO e ACCURSIO são famosos por obras desta natureza. Entre os portuguezes, compuzeram e colleccionaram formulas Caminha, Mendes de Castro, Vanguerve, Gomes, Correa Telles, Menezes e muitos outros, entre os brasileiros, notaremos Pimenta Bueno, Teixeira de Freitas, Cordeiro, Coroatá, Vasconcellos, Ferrão, MaCHADO, etc. Não abandonemos, portanto, a leitura dos

(1) Vejam-se as formulas compiladas por Canciani, na sua colleç̧ão dis Leges Barbarorum, vols. II e III. Ahi se encontram as formulas de MABILlon, de Marculfo, de Sirmond, de Goldast, de Baluze, de Lidenbrog e outras. As formulas de Mabillon, escriptas no seculo VI, foram achadas em seguida ao Breviarium de Alarico, manuscripto; as de Maculfo, foram escriptas no seculo VII; as outras "colleç̧ões estão annexas a codigos dos povos invasores lavradas quasi sempre por moryes e outros clerigos e escriptas em latim. Nas leis lombardas são ifrequentes as formulas intercaladas no texto. 
formularios, ahi teremos uma obra a imitar, um exemplo a seguir, um modelo a aproveitar (1)

Quando o governo recommenda algum formulario toma elle a denominação de formulario official. Entre nós o unico formulario official foi o de PIMENTA BUENo, para o fôro criminal, recommendado pelo aviso circular de 23 de Março de 1854 e revisto, depois do Dec. n. 4824 de 22 de Novembro de 1871, pelo conselheiro MANOEL DA SILva MAFRA.

Mais adiante, em logar opportuno, daremos noções desenvolvidas sobre as formulas forenses.

\section{CAPITULO III}
SumMARIO - A pratica forense e o ensino-Methodo desta disciplina. A pratica forense e a experien- cia-Relações entre a pratica forense $e$ os di- versos ramos das sciencias sociaes $e$ juri- dicas.

A cadeira de Pratica Forense figurava no projecto de Estatutos das Faculdades de Direito, organisado pelo Visconde de Cachoeira, e cuja integra vem annexa á lei de 11 de Agosto de 1827 Esta Lei, porem, unia essa disciplina, na segunda cadeira do quinto anno, com a Theoria do Processo; e assim permaneceu até o recente Dec. n. 1232 de

(1) BACon, De lignitate et augmentis scientiarum, no Aphorismo LXXXVIII assim se exprime: Formuas agendi diversas in unoquoque genere colligito. Nam et praticae hoc interest; et certe pandunt illae oracula et ucculta lgum. Sunt enim non pauca, quae latent in legibus: at in formulis agendi, melius et fusius perspiciuntur instar pugni et palmaxe: "Sejam colligidas, em cada genero, as diversas formulas dos actos. Isso, é muito aproveitavel na pratica, porque as formulas manifestam os oraculos e mysterios das leis. Não são poucas as idéas que se occultam nas leis; e, nas formulas, ellas apparecem e surgem claramente, á semelhança da mão fechada que se abre" 
2 de Janeiro de 1891, o qual reformando as instituições do ensino juridico, creou a $4 .{ }^{a}$ cadeira da $4 .{ }^{a}$ serie do Curso de Sciencias Juridicas especialmente para a instrucção da pratica forense.

Os Estatutos da Universidade de Coimbra, que até certo ponto serviram de molde ao projecto do Visconde de Cachoeira, assim dispunham no Liv. II, tit. cap. III, ns. 51 e segs.:

"51. Em todos os titulos da dita compilação philippina e do compendio, que se deve formar por or̃dem della, ensinará o professor não só o uso, que tem o direito que nella se inclue, mas tambem o melhor modo que ha de usar delle e de exercital-o na pratica. Com esse fim dará a conhecer aos ouvintes as cautelas e as formulas com que se deve expedir e celebrar os negocios, que fizeram os objectos da jurisprudencia delles.

"52. Apontará, pois, as cautelas justas, uteis e ainda necessarias, para que, na celebração dos contractos e testamentos se acautelem as fraudes, os dolos e as maquinações da astucia e da má fé dos contrahentes e interessados. E a tudo isto se occorrerá providamente: prevenindo-se as demandas, que se podem mover para se illudir a boa fé e a justa intenção dos contrahentes e dos testadores; para que no caso de se chegarem a mover as ditas demandas, se possam acabar mais depressa na forma das leis e se não tornem depois a exercitar.

"53. O que o professor fará, ou os negocios de que os respectivos titulos se tratar, pertençam á jurisdicção contenciosa ou voluntaria: porque em todos é muito conveniente a noticia das ditas cautelas para se evitarem as ditas nullidades. Concluirá finalmente, dando a conhecer aos ouvintes, que a maior parte da jurisprudencia eurematica consiste no bom conhecimento da natureza dos negocios que se celebram e de todos os requisitos e circunstancias delles. 
“54. A' util e interessante instrucção da jurisprudencia eurematica ajuntará o professor a da jurisprudencia formularia, não menos necessaria no uso e na pratica do direito. Ensinará, pois, e explicará aos ouvintes as formulas, de que devem uzar na expedição dos negocios, que deram materia á jurisprudencia do titulo que explicar; o justo valôr das mesmas formulas, e a necessidade que ha, ainda no tempo presente, de conhecel-as"

Segundo o plano destes Estatutos, os mesmos professores das Cadeiras de Direito Civil Patrio, deveriam ensinar as euremas e formulas em relação a cada titulo das Ordenações; entretanto, na execução, foi creada uma cadeira especial, sob a denominação de - Pratica formularia, cujo primeiro professor foi o doutor José Ignacio da Rocha Peniz, que escreveu um compendio. A arte de applicar as leis aos factos foi considerada como disciplina especial e distincta da jurisprudencia pratica, para ser ensinada com a arte da interpretação das leis, como se poderá ver do Cap. VIII, do cit. tit. IV do L. II desses Estatutos:

"1. Formado, que seja o interprete por meio das regras, prenoções e subsidios da Hermeneutica Juridica, e do exercicio e da pratica delles, proseguirá o Professor as suas lições com a doutrina da applicação das leis aos factos e casos occurrentes no fôro.

"2. Sobre a applicação das leis aos factos, fará o mesmo professor todo o possivel para dar aos ouvintes as mais verdadeiras e claras noções, expondo-lhes a natureza, o fim, o objecto, as prenoções e os subidios della; e o methodo, com que nella se deve proceder para se conseguir o acerto.

“3. Dirá que a applicação das leis é um juizo pratico de que o caso, ou a acção, se deve decidir pela lei, que tem determinações communs com elle.

"4. Dirá que, para a applicação das leis se poder fazer com a dexteridade necessaria, deve primeiro que tudo comprehender-se bem o caso proposto com todas as deter- 
minações ou circunstancias essenciaes delle, deve explorarse a natureza do niegocio, de que nelle se trata, deve formar-se o estado da questão; deve verr-se em que consiste o ponto da duvida; deve resumir-se e recolher-se a substancia della em uma ou mais proposições, que exprimam bem a natureza do negocio e de todas as circunstancias substanciaes delle. Concluirá que, sendo assim resumido e reduzido o facto, se deve procurar qual é a lei do Estado, que foi estabelecida para norma da acção e do negocio no caso das circunstancias delle, porque esta é a lei pela qual o dito caso deve ser decidido.

“5. Dirá que, para se achar esta lei, é necessario indagarem-se as leis que ha para a regulamentação do referido negocio; é necessario procurar-se a que mais se chega para as circunstancias do caso, e considerar-se o que ella determina, isto é, o que ella manda fazer e omittir, ou seja absoluta e geralmente, ou somente debaixo de certas circunstancias.

"6. Dirá que a determinação adequada da lei, assim considerada e comprehendida por meio das operações da analyse e da hermeneutica juridica, se deve confrontar com a determinação tambem adequada e já comprehendida do facto, isto é, com a natureza do negocio e com todas as circunstancias essenciaes delle: e que, constando serem as determinações do facto as mesmas da lei e serem ambas communs, então se deve a lei ter por norma da acção, que no dito facto se obrou: e por ella se deve o mesmo facto decidir e julgar"

Esta distinç̧ão entre a arte da applicação das leis e as duas partes da jurisprudencia pratica veio afinal, a ser considerada como despida de fundamento real ou logico. Na mesma Universidade de Coimbra, a arte da applicação das leis passou a ser considerada como a principal cantela do jurisconsulto pratico e, por isso, como a parte mais importante da jurisprudencia eurematica. A arte da applicação das leis ou hermeneutica juridica passou a constituir ca- 
deira especial, com a analyse dos textos de direito patrio, romano, e canonico e com a diplomatica. Assim a jurisprudencia pratica ou pratica forense, ficou com o seu objecto perfeitamente definido: applicação das leis aos factos e casos occurrentes no fôro, o que se consegue mediante cautelas e formulas.

Vamos agora determinar o methodo desta disciplina.

Já dissemos que o primeiro professor da Pratica Forense, na Universidade de Coimbra, foi o DR. JosÉ IGNACIO DA Rocha PENIZ. Escreveu um compendio que intitulou - Elementos de pratica formularia ou breves ensaios sobre a praxe do fôro portuguez. Esse livro traz como prefacio, a oração inaugural da cadeira e o seguinte plano de methodo: "Faltando compendio nacional e estrangeiro, formado no plano dos Estatutos, repartirei a theorica da Pratica Formularia em oito divisões. Cada uma divisão comprehenderá as materias entre si mais analogas, destribuidas por titulos e paragraphos, e fundamentadas na lei, nos praxistas de que ella foi tirada, nos reinicolas que a entenderam, e estranhos acreditados no fôro de todas as nações. A summula da theorica formularia occupará as lições e sabbatinas desde Outubro até Março, em Abril e Maio, as lições se reduzirão a exercicios escriptos e vocaes sobre actos, causas e incidentes usuaes no fôro"

Desse compendio escripto para o anno lectivo de 1807 e 1808, apenas existe impresso o primeiro volume, com tres partes assim generalisadas. I) conhecimentos communs ao exercicio da jurisdicção contenciosa e voluntaria; 2) Processos e suas diversidades; 3) Actos que formam o processo. O illustrado professor não se mantem subordinado á natureza pratica de sua cadeira, pois, no texto desse compendio, quasi semone, torna-se mais theorico do que earematico, entrando desassombrado en demonstrações scientificas e elucidações historicas sobre as formas intrinsecas do processo. Nenhum outro compendio existe desta materia escripto en portuguez; mas não faltam ma- 
nuaes e tratados, taes como os de CAMINHA, MENDES DE: Castro, Vanguerve, Alexandre Caetano Gomes, Moraes, Córrea Telles, TeiXeira de Freitas, e outros.

Tratando-se de uma disciplina eminentemente artistica como é a Pratica Forense, os processos de ensino devem ser mais de applicação do que de exposição. Comtudo, sendo esta arte muito dependente da prudencia, a indicação. das cautelas deve preceder á composição das formulas. Esgotada a parte eurematica ou a exposição das cautelas, terá principio a confecção das formulas, mediante os methodos do ensino applicado, os quaes consistem: 1) na reproducção graphica das formulas; 2) na transformação, isto é, na applicação aos casos analogos e ás variaveis circunstancias dos factos, 3) na imitação do movimento processual. O professor corrigirá os exercicios escriptos: e dirigirá a imitação do movimento processual.

Os citados Estatutos da Universidade de Coimbra eram explicitos na determinação desses processos de ensino. applicado (1)

(1) Eis o methodo dos citados Estatutos, conforme se acha no L. II, tit. VI, cap. III:

"56. E para que as lições que se derem sobre a jurisprudencia eurematica e a formularia, se imprimam mais fixamente no espirito dos ouvintes; depois de se explicar bem a materia de cada titulo e de se darem todas as noções necessarias da natureza e de todos os requisitos substanciaes do negocio, de que nellese tratar; mandará o professor a alguns dos ouvintes que apontem as cautelas e componham a formula, em que elle se deve celebrar e expedir; ensinando-lhes que devem ordenar esta de sorte que, nella se inclua e se dê bem a conhecer a natureza do dito negocio, e se comprehendam todos os requisitos para elle necessarios".

"57. Examinará depois as cautelas e as formulas que os discipulos tiverem composto, perguntando-lhes pelas razões das clausulas que nellas incluirem, accrescentando as substanciaes que elles tiverem omittido, e tirando as superfluas que nellas redundarem" Estatutos:

Mais adiante, nesse mesmo Livro II, tit. VI, porem no cap. IV, dizem os

“10. Não se conterá porem, o Professor com a simples e precisa exposição. das regras e dos preceitos das doutrinas do processo judicial. Ensinará tambem o uso dellas e ensaiará nelle os ouvintes.

"11. Os exercicios da Pratica costumam ser de dous generos. Uns se executam, compondo-se e formando-se as diversas especies de escriptos, que fazem objectos dos differentes officios do jurisconsulto: ou os ditos escriptos sejam extrajudiciaes, como são as escripturas dos contractos, as cedulas dos testamentos. e codicillos, e todos os outros instrumentos, que se costumam fazer para prova. 
A pratica forense póde, assim, tornar-se conhecida pela doutrina e pela disciplina; mas não se aperfeiçoa senão com o auxilio da experiencia.

A experiencia depende da observação e do exercicio. Pela observação dos casos singulares e pelo habito do trabalho, o artista forense adquire facilidade e segurança na operação. "Não ha esphera do saber e do poder humano, diz Ihering (Obra Cit., III, 13), na qual o mais fraco que saiba aproveitar os dados da experiencia não seja superior ao genio que abandona este soccorro" Dahi resulta a importancia que para a pratica forense, tem os estylos do fôro, os casos julgados, os arestos dos juizes e tribunaes.

Com o auxilio da experiencia - o artista forense evitará as apalpadellas confusas do operario novo. $\mathrm{O}$ bom senso popular creou o seguinte dictado: mais util é a experiencia sem arte do que a arte sem a experiencia. Com effeito, sendo os actos humanos casos singulares, o homem experiente, pela memoria e comparação desses casos singulares, menos errará, em casos semelhantes, do que o sim-

\footnotetext{
das convenções e dos ajustes, que entre si fazem os cidadãos sobre os negocios rque tratam; e as clausulas, cautelas e formulas substanciaes, que em todos elles se devem incluir, para se segurar a justiça dos contrahentes e interessados: - ou os mesmos escriptos sejam judiciaes, como são os requerimentos e petições para citações e outros fins, os libellos, as execuções peremptorias ou dilatorias as contrariedades as replicas as treplicas, as recone'enções, as allegações de direito, asł tenções ou ou vótos escriptos pelos ministros nos feitos, que hão de julgar simultaneamente no Senado, as sentenças interlocutorias ou definitivas, os embargos a ellas, e outros semelhantes.

"12. Outros dos sobreditos exercicios se executam, resolvendo-se e fazendo-se analyses, ou estas sejam do facto e dos documentos, que ha para proval-o, antes de se proporem em juizo, para se provarem o estado da questão; para se comprehenderem os pontos sobre que ha de versar a demanda; para se conhecer si ha acção e qual é a competente; para se explorar si a que compete, é efficaz ou inefficaz, por causa de alguma excepção, com que se possa elidir; e para se poder formar um juizo certo e seguro da justiça do Autor ou do Réo, e, em conformidade delle, se resolverem os casos, se aconselharem as partes e se dirigirem as causas. Ou a mesmas analyses sejam do feito, em que se tiver já processado a acção; para delle se extrahir o succo e a substancia do facto, sobre que nelle se litiga, com todas as circumstancias delle necessarias e do merecimento das provas; com o fim de se conhecer a justiça da causa; de se deduzir e de se applicar o direito, e de se poder fazer a breve exposição, que devem fazer, assim ros julgadores inferiores nas sentenças que preferem por si sós, como tambem as juizes relatores no Senado ans Ministros seus adjunctos, para que sendo plena-
} 
ples artista apenas instruido com as regras da arte. Quantos jurisconsultos cheios de sciencia e certos das regras da arte forense, são ineptos para a vida activa? Quantos professores de direito, famosos pela profundidade de saber e pela perfeição do methodo, entregam-se aos deleites da pura contemplação, tornam-se incapazes de attender ás minudencias de um caso particular, aos embaraços e complicações da pratica? Muitas vezes, na vida forense, o jurisconsulto mais profundo pedirá conselho ao solicitador antigo e exercitado. O artista forense, para ser perfeito, deve, por conseguinte, ter o talento da observação $e$ o habito do trabalho (1)

mente informados de todo o merecimento dos feitos, possam sempre administrar inteira justiça, ainda que nem sempre possam examinar e fazer por si mesmos as sobreditas analyses dos feitos".

Os cit. Estatutos descem a exemplificar o modo de proceder a estes cxercicios, indicando ao Professor o seguinte caminho:

"14. Proporá aos mesmos ouvintes um acto revestido das circunstancias necessarias, de que lhe parecer revestil-o. Mandará que figurem por elle o caso de uma demanda forense e que escolham nelle os pontos que podem servir para se mover e sustentar um litigio; que explorem e declarem a natureza do negocio de que nelle se tratar; que examinem bem qual é a legitima acção que por elle compete; que depois de a conhecerem com toda a clareza, formem o libello em que ella se deve intentar; narrando nelle o facto com as circunstancias precisamente substancizes, ou para concluir a mesma acção em direito, ou para a provar juridicamente, si consistir em facto; deduzindo o direito do Autor e concluindo não só com o petitorio conforme a acção, mas tambem com a designação da mesuna acção e com o meio de pedir, que a ella corresponde.

"15. Formados que sejam os libellos, os lerá o Professor e os emendará. declarando os defeitos e os erros que nelles se tiverem acommettido.

"16. Depois de examinar e corrigir os libellos mandará que se autuem por um ouvinte, que sirva para processal-os; que outros sirvam de advogados para contrariar, replicar, triplicar, propor e contrariar excepções, formar os artigos necessarios, deduzir o direito nas allegações juridicas; examinar as testemunhas e documentos authenticos; e proferir-se a sentença final.

“17. Deste modo fará seguir este processo na aula, não só na primeirł instancia, mas tambem na segunda a qual ordenará como si fosse de Relaçãa, para exercitar tambem os ouvintes em tencionarem e relatarem os feitos; exami. nando, corrigindo e emendando todas as composições, que elles forem formando, c pedindo-lhes sempre as razóes do que nellas executarem".

(1) O habito, adquirido pela repartiçâo frequente dos actos, tem os seguintes ef́feitos: 1) torna as operaçóes rapidas e facilita-lhes o exercicio; 2) torna as operações seguras e perfeitas; 3) torna as operaçóes até agradaveis. A actividade forense, como qualquer outra manifestação da actividade livre do homem, resolve-se no movimento voluntario, o qual se realisa por meio dos orgams; ora, é principio scientifico, universalmente reconhecido, que todo o orgam se atrophia pela inercia e desenvolve-se pelo exercicio. Dahi vem a razão pela quå se diz rque o habito é uma segunda natureza. 
Os legisladores, desde os tempos mais remotos, têm exigido, nos homens incumbidos de applicar o direito aos factos, a experiencia dos negocios e o habito de julgar. Assim, na Novella LXXXII, pric. e cap. I, diz o imperador Justiniano: Non enim existimavimus opportere habere judicium quorundam nomina, maxime legum incruditorum, deinde neque causarum experimentum... Quia vero competes est esse etiam majores judices aliquos dignitate provectos, experimiento causarum multarum, aut plurimi temporis exercitatos magnis cingulis, aut multitudine horum exercitatos.

$\mathrm{Na}$ legislação patria, desde a Ord. Liv. I, tit. V, relativa aos desembargadores da Casa de Supplicação até os ultimos projectos de Organisação Judiciaria, em todos os Estados do Brasil, — é condição para a investidura dos Juizes um previo tempo de exercicio da profissão forense.

A experiencia é, pois, indispensavel para o aperfeiçoamento do jurisconsulto pratico: — pela observação, ella produz o conhecimento mais completo das regras da arte de applicar as leis aos factos; pelo habito do trabalho, ella produz uma certa aptidão que torna a operação mais facil, pela observação e pelo habito de trabalho, ella produz a convicção da possibilidade do exito, isto é, a esperança e a coragem para resistir aos embaraços da vida activa.

- Si ás regras da arte e aos dados da experiencia forem addicionadas as demonstrações da sciencia, então o jurisconsulto pratico attingirá ao maior gráo de perfeição. A pratica forense relaciona-se intimamente com todos os ramos das sciencias juridicas e sociaes: vae buscar no Direito Publico e Constitucional a garantia dos direitos individuaes, a organisação judiciaria e dos serventuarios da justiça, no Direito Civil e Commercial, os elementos dos actos juridicos; no Direito Criminal, a classificação legal dos actos illicitos; na Medicina Legal, a solução dos problemas medico - judiciarios, relativos á identidade, á idade, ao 
sexo, á responsabilidade, á alienação mental, á vitabilidade, ao cadaver, e as questões relativas a homicidios, lesões corporaes, asphyxias, envenenamentos, etc.; na Historia do Direito Nacional, as vicissitudes por que tem passado a administração da justiça e a experiencia resultante da observação dos factos, na Theoria do Processo Civil e Commercial e Criminal, as formas intrinsecas das acções e os termos legaes do processo; no Direito Internacional, as atribuições dos funccionarios diplomaticos, as convenções sobre extradicção e cumprimento de rogatorias e deveres dos consules e agentes consulares, os quaes muitas vezes servem de officiaes publicos para negocios forenses; na Economia Politica, dados para a avaliação dos objectos, para os titulos de credito, os quaes quasi sempre são destinados á prova judicial, no Direito Administrativo, os regulamentos das diversas repartições que despacham documentos destinados á prova judicial, os regulamentos fiscaes para pagamento do imposto de transmissão, para pagamento do impoto de sello dos contractos e documentos, para averbação dos mandados e alvarás relativos a apolices e a outros papeis de credito publico, etc.

Emfim a pratica forense, em suas numerosas manifestações, recorre a todos os conhecimentos scientificos e artisticos, a todas as profissões que possam, em um caso dado, determinar as circumstancias de facto a que se pretenda applicar a lei. 
TITULO II

A actividade forense

\section{CAPITULO I}

SummaRIo - Fôro - Actividade juridica e actividade forense - Causas da actividade forense.

Fôro é o lugar publico onde as autoridades judiciarias, assim como os serventuarios e empregados da justiça, exercem as suas funç̧ões (1)

A principio, antes da instituição dos tabelliães e escrivães publicos, sómente trabalham no fôro os magistrados. Creados os tabelliães e escrivães, attribuida a elles a qualidade de officiaes publicos, ficou logo entendido que elles exerciam suas funcções em logares publicos que os Romanos denominavam stationes, os Portuguezes paços de tabelliães (2) e cartorios, e que nós denominamos simplesmente cartorios. O lugar dos cartorios está, pois, contido na expressão - fôro; tanto é assim que, nos Estatutos da Universidade de Coimbra, Liv. II, tit. VI, cap. III n. 55, encontra-se a expressão - Estylo do Fôro civil, empregada em contraposição á expressão - Estylo do fôro judicial e claramente destinada a significar o estylo das formulas feitas nos cartorios dos tabelliães e escrivães. Aliás, na linguagem vulgar, são considerados funccionarios forenses, não só os magistrados, mas tambem os tabelliães, escrivães

(1) Varias tem sido as accepções da palavra fôro, as quaes podem ser vistas desenvolvidamente, no vocabularium de Vicat, I, 344, verb. Forum. A origem dessa palavra está nas Decretaes, Liv. V, Tit. $\mathrm{XL}_{\text {, }}$ de verb signif, cap. $\mathrm{X}$, extrahida do Livro das Etymologias, de S. Isidoro.

(2) Candido Mendes, Cod. Phillip., nota 1 á Ord., LL. I, tit. LXXVIII, pr. 
e mais serventuarios e empregados da justiça; e hoje se diz: - fôro extrajudicial para significar o logar em que trabalham os tabelliães e officiaes de notas e registros; fôro judicial, o lugar em que trabalham os juizes, escrivães e mais officiaes de justiça.

Por extensão, se diz - serviço forense - não só o trabalho dos juizes em seus auditorios, o trabalho dos tabelliães, escrivães e mais officiaes em seus cartorios, o trabalho dos advogados e solicitadores em seus escriptorios, como tambem o trabalho de qualquer desses funccionarios em diligencias e audiencias, isto é, o trabalho fóra dos auditorios, cartorios e escriptorios, desde que seja destinado a assegurar a realisação do direito de alguem.

- O homem realisa o direito pela actividade juridica e assegura a realisação do direito pela actividade forense.

Quando, na vida social, surge qualquer relação de direito, apparece a simples actividade pessoal, isto é, a actividade juridica; quando porem, para prevenir ou para evitar ou remover a violação do direito, a actividade pessoal recorre á acção ou ao testemunho dos agentes do poder judiciario, apparece a actividade forense. Dahi as seguintes consequencias:

1) Que a actividade juridica refere-se ás formas intrinsecas dos actos juridicos e ás formas extrinsecas dos actos forenses.

2) que a actividade forense refere-se propriamente ás formas extrinsecas destinadas a servir no processo: isto é, - que a actividade forense refere-se propriamente ás formas extrinsecas praticadas pelos juizes, pelos tabelliães e escrivães, pelos outros officiaes publicos e pelos advogados e solicitadores, mas, por extensão, refere-se tambem ás fórmas extrinsecas praticadas exclusivamente pelas partes, quando estas destinarem taes formas a provar em juizo os respectivos actos. 
- Qualquer facto humano suppõe causas preexistentes: um agente que o fez, - a materia de que é feito, aquillo que o agente fez, - o fim para que fez; isto é:

1) um principio activo productor, dotado da necessidade força intellectual e physica, - o qual se denomina agente ou causa efficiente;

2) um principio passivo, dotado de potencialidade para receber uma determinação, o qual se denomina materia ou causa material e póde ser corporeo ou incorporeo;

3) uma determinação ou acto, que se chama forma ou causa formal, a qual póde ser intrinseca (ut species) ou extrinseca (ut exemplar),

4) um termo para o qual se dirija o facto, quer pela intenção do Autor (finis operantis) quer pela tendencia do movimento (finis operis), termo esse que se chama causa. final ou fim, que pode ser attingido por actos que se denominam meios, se não ha impedimento, ou por uma acção que, tendendo a remover impedimentos se denomina - remedio.

Essas causas movem ou são movidas no espaço e no. tempo. O facto humano está, pois, subordinado ás realidades contidas nas idéas de força, materia, forma, fim, movimento espaço e tempo.

Para applicar estes principios aos factos forenses, faremos mais as seguintes considerações:

1) A materia é a substancia em potencia, a forma é a: substancia em acto, a causa material ou parte determinavel e a causa formal ou determinação - constituem, por sua união, o ser do effeito, o ser do composto.

2) A materia, conforme o modo de consideral-a, divide-se em materia prima e materia segunda. Chama-se materia prima, quando é considerada como já provida de uma forma e com aptidão para receber uma forma peculiar. 
3) As formas forenses applicam-se aos actos juridicos já constituidos em sua especie ou forma intrinseca, isto é, aos actos juridicos já constituidos em materia segunda. Assim: no fôro extrajudicial, a materia da actividade forense são as diversas especies de contratos, testamentos e registros; - no fôro judicial, são as acções, os actos processuaes, taes como a preposição da acção, as excepções, a contestação, a reconvenção, a replica, a treplica, as provas, as razões finaes, o julgamento, os recursos, a execução, etc. Estas materias segundas e as respectivas formas extrinsecas constituem, por uma união, o ser do composto denominado - forma forense.

4) As formas extrinsecas consistem em todas as representações sensiveis ou signaes, quer naturaes quer artificiaes: gestos, symbolos ou palavras - podem traduzir a forma intrinseca em forma extrinseca. Mas, no estado actual da jurisprudencia pratica somente a palavra é adoptada para representar os actos juridicos (1)

5) Depois do desenvolvimento da arte de escrever. veio a palavra escripta servir não para substituir, mas para representar a palavra fallada. Antigamente, os actos forenses deveriam ser sempre concluidos oralmente; e, mesmo agora, nas formulas, conservam-se expressões que significam previa conclusão oral, da qual, aliás, muitos actos ainda dependem. Entretanto, quer reproduzindo palavras falladas, quer referindo a intenção dos agentes, não se con-

(1) A symbolica do direito cedeu lugar a diplomatica e á paleographia, diz Savigny. Os Romanos, que a principio declaravam sua vontade juridica por symbolos e signaes, atravessando as phases do progresso plastico, chegaram a declaral-a por palavras que deveriam ser sacramentalmente pronunciadas; mas, esse rigor foi abolido, nos annos 348 e 428, por determinações dos Imperadores Constancio, Theodosio e Valentiano, leis que se acham insertas no Cod. L. II, tit., XVIII. Juris formulae, diz o Imperador Constancio, aucupatione syllabarum ënsidiantes cunctorum radicibus amputentur. 
sidera como forma forense, na technica moderna, senão a forma escripta. (1)

6) As formas forenses são sempre destinadas a provar judicialmente os actos juridicos: as do fôro extrajudicial são destinadas a provar estes actos, si for violado 0 direito que ella manifestam; as do fôro judicial são destinadas a provar as affirmações das partes feitas em juizo e as decisões dos juizes (2)

7) Considerada a materia como indifferente a constituir tal ou tal acto, isto é, como materia prima, ha necessidade de um principio que a determine a formar tal especie $e$ acto $e$ não tal outra especie (3) Este principio é a forma substancial e distingue-se da forma accidental, porque na forma substancial considera-se a essencia, prescindindo de qualquer modificações; ao passo que a forma accidental accrescenta modificações á essencia já construi$d a$, e, portanto sobrevem ao acto, já provida de sua especie. Assim, rigorosamente fallando, a forma substancial é sem-pre uma forma intrinseca, porem, a forma accidental póde ser intrinseca ou extrinseca, visto que as modificações ac-crescentadas á essencia — podem ser intrinsecas ou extrinsecas. Mas, estas noções abtractas não são, na technica juridica, empregadas na sua rigorosa significação: - a lei, algumas vezes por necessidades de ordem pratica ou por motivos de ordem publica, dá a forma accidental a virtude de constituir ou completar a essencia de certos actos; e, então, por analogia, essa forma accidental toma a denominação de forma substancial. Por exemplo: a edade maior de. vinte e um annos, simples forma accidental intrinseca da. existencia do homem, é, em regra forma substancial da capacidade para o livre exercicio dos actos da vida civil; a

(1) Teixerra de Freitas, Introd. ao Formulario do tabelliunato, pg. XXIV.

(2) Decretaes, L. II, tit. XI, de probationibus, cap. XI, Quoniam contra.

(3) Nesse sentido se diz: Forma dat esse rei. 
escriptura publica, simples forma extrinseca para contractos e testamentos, é forma substancial da hypotheca convencional.

Esies principios justificam a seguinte definição:

A actividade forense é a actividade humana dando aos actos juridicos, já constituidos em suas especies, uma forma litteral, destinada a dar-lhes substancia legal.

$\mathrm{Na}$ definição estão contidas as quatro causas supra expostas: a causa efficiente, a causa material, a causa formal e a causa final.

\section{CAPITULO II}

SUMmario - Causas efficientes da actividade forense: causa principal e causa instrumental-Enumeração dos agentes - Cautelas em relação á qualidade e quantidade dos agentes Cautelas em relação ao movimento.

A causa efficiente é principal ou instrumental. Assim, o artista é a causa principal do artefacto; os orgãms de seu movimento e os instrumentos de que se serve, são a causa instrumental. Nesse sentido, por exemplo, o tabellião, as partes e as testemunhas - são a calisa principal da escriptura publica, os orgams de seu movimento e a penna de escrever são a causa instrumental.

A causa efficiente insirumental da actividade forense não é, portanto, a causa efficiente instrumental da arte da leitura e da escripta. Basta-nos, pois, na enumeração dos agentes, determinar os que se comprehendem na causa 
principal. Entretanto, como os orgams do movimento funccionam no tempo e no espaço, a causa instrumental se une inseparavelmente a essas duas realidades, por isso, diz HeRBert SPENCER (Primeiros principios, Port. II, cap. III, $\ 49)$ - que as concepções do movimento, espaço e tempo tiram sua origem das impressões numerosas e diversas da tensão muscular. Decorre dahi a necessidade logica de considerar o tempo e o espaço em relação ao exercicio da causa efficiente ou força motriz.

Em um sentido todo peculiar á theoria do processo, os agentes que constituem a causa efficiente principal - costumam a ser divididos em agentes principaes e agentes auxiliares. Assim, as partes são, nos actos do fôro extrajudicial, os agentes principaes; e no fôro judicial, os agentes principaes são as partes e o juiz: todos os outros são agentes auxiliares. Está claro que, na pratica fosense, essa distincção não prevalece. Por exemplos: o agente principal da formula denominada - termo de autuação - é o escrivão e somente o escrivão; os agentes principaes do depoimento da testemunha são - a testemunha que depõe, as partes ou seus procuradores que perguntam ou reperguntam ou contestam, o escrivão que reproduz as perguntas e respostas e o juiz que assiste e dirige, pois todos esses agentes são imprescendiveis para a inquirição.

$\mathrm{Na}$ pratica, todas as cautelas relativas á causa efficiente devem versar sobre a aptidão dos agentes para reproduzirem uma operação valida; por conseguinte, essas cautelas versam: 1) sobre a legitimidade dos agentes; 2) sobre a sua capacidade civil, a) sobre as suas attribuições e competencia; sobre o sell movimento no tempo e no espaço, isto é, sobre o modo de exercer suas funç̧ões. Em resumo, versam essas cautelas sobre a qualidade e quaniidade e sobre o movimento dos agentes. 
- Na enumeração dos agentes que constituem a causa principal efficiente da actividade forense - teremos em vista a classificação que, na pratica, mais possa aproveitar, isto é, consideraremos 1) Partes, seus representantes, seus assistentes; 2) Orgams do Ministerio Publico; 3) Juizes e autoridades policiaes, 4) Serventuarios e empregados da justiça; 5) Auxiliares do juizo na verificação dos objectos e factos presentes; 6) Testemunhas.

$\mathrm{Na}$ seguinte tabella melhor será explicada esta classificação

I. - Partes. Procuradores. Tutores e curadores, Testamenteiros. Syndicos.

\section{Partes:}

a) O outorgante, o outorgado; o terceiro interveniente (1). O testador (2). O saccador, o aceitante, o endossante, o portador; 0 protestante (3)

(1) Não podem contractar: os impuberes (Ord. L. III, tit. $29 \S 1$, tit. $41 \S 8$, tit. $63 \S 5$; Cod. Comm., art. 129 n. 1); os alienados, declarados taes em juizo (Ord. L. IV, tit. 103, Lei de 3 de Nov. de 1830, art. 4, Reg. n. 834 de 2 de Out. de 1851) os prodigos, declarados taes em juizo (Ord. L. IV, tit. 103, Aviso n. 246 de 5 de Julho de 1873; os surdos mudos, que não sabem dar-se a entender por escripto (argm. da Ord. L. IV, tit. 81, § 5). Convem lembrar que as incapacidades são de facto ou de direito e que as incapacidades de facto sẫo absolutas ou relativas. As de direito e as relativas pertencem á eurematica particular, isto. é, serão apontadas por occasião de cada um dos contractos. Outrosim, por estas pessoas, affectadas de incapacidade de facto absoluta, contractam os seus representantes legaes.

(2) Não podem fazer testamento: 1) Os menores de quatorze annos e as menores de doze (ord. L. IV, tit. 81, pric.); 2) Os filhos familias; ainda que os paes consintam, excepto quanto aos bens castrenses ou quasi castrenses (ord. L. IV. tit. $81 \S 3$, tit. $83 \S 1$ e tit. $91 \S 1 ; 3$ ) Os prodigos interditos (Ord. L. IV, tit. $81 \S 4$ ); Os mudos e surdos de nascença, entre os quaes não se comprehendem os que escrevem e fallam com difficuldade, assim como os que sabem escrever (Ord. L. IV, tit. $81 \S 5$ ) ; 5). Os religiosos professos (Ord. L. IV, tit. 81 § 4); 6) Os alienados ou furiosos, salvo em lucidos intervallos (Ord. L. IV, tit. 81 princ.).

(3) Cod. Comm. arts. 405 a 414. 


\section{b) o supplicante, o supplicado (1). O autor, o réo, o chamado a autoria, o assis- tente, o oppoente (2) O exequente, o ex- cepto (3) O citado (4), o notificado}

(1) A todos é garantido o direito de petição (art. $179 \S 30$ da Const. do Imperio e art. $72 \S 9$ da Constituição da Republica).

(2) Não podem ser autores no Juizo Civel, as pessoas civilmente incapazes, que não estejam representadas ou assistidas legalmente, e taes são: 1 - Os nascituros (Ord. L. III, tit. $18 \S 7$ ) ; 2 - os menores de vinte annos (Ord. L. III, tit. $29 \S 1$, tit. $41 \S 8$ e 9 ; tit. $63 \S 5$; Lei de 31 de Outubro de 1831); 3 - as mulheres casadas salvo nos casos excepiuados pela lei (Ord. L. III, tit. 47 e L. IV, tit. 103) $5-0$ s prodigos interdictos (Ord. L. IV, tit. $103 \S \S 6$ e seguintes) $6-$ os mudos e os surdos não educados (arg. da Ord. L. IV, tit. 81 5); os fallidos (Dec. n. 917 de 24 de Outubro de 1890, art. 25) Tambem não podem ser autores: 1 - Os maridos, em acção sobre dominio de bens de raiz (Ord. L. I, tit. 79 \& 22, L. III, tit. 47 , tit. $63 \S 1$, tit. $70 \S 4$ ) 2) - Quaesquer representantes necessarios sem autorisação judicial, salvo em medidas assecuratorias e de urgencia (TEIXERRA DE Freitas, edic. das Primeiras Linhas de Perlira de Souza, $\&$ XXXV, n. 3); $3-0$ cabeça de casal, sem mandato dos herdeiros, salvo nas acções possessorias (Ord. L. IV, tit. 95; Moraes Carvalho, Praxe forense, nota 46). 0 autor não póde demandar mais do que lhe é devido (Ord. L. III, tit. 34 nem antes do tempo a que seu devedor lhe é obrigado (Ord. L. III, tit. 36). Póde o autor desistir de sua aç̧ão antes de contestada, pagando as custas; e depois de contestada pode desistir com acquiescencia do Réo.

Não pódem ser Réos, sem que sejam legalmente representadas ou assistidas, as mesmas pessoas que não podem ser autores e mais: os ausentes (Reg. n. 737 de 25 de Novembro de 1950, art. 45); os presos e affiançados (Lei de 11 de Setembro de 1830 , art. 3

Quanto ás pessoas juridicas, essas por sua propria natureza, dependem de representação.

O chamado á autoria, o assistente e o oppoente, quando civilmente incapazes, tambem não pódem intervir em juizo sem representação ou assistencia (Regul. n. 737 de 25 de Novembro de 1850, art. 111 a 126; Dec. n. 848 de 11 de Out. de 1890 , arts. 149 a 136$)$.

(3) Regul. n. 737 de 25 de Novembro de 1850, art. 74: a 95; Decr. ns. 763 de 19 de Setembro de 1890; dec. n. 848 de 11 de Outubro de 1890, arts. 122 a 138.

(4) Reg. n. 737 de 25 de Nov. de 1850, art. 29 a 59; Dec. n. 848 de 11 de Outubro de 1890, art. 98 a 115 ; Dec. n. 720 de 5 de Setembro de 1890, arts. 1 a 18. Cod. de Processo, arts. 81 a 83 . Por incuria dos juizes, escrivães e advogados, tem-se usado indifferentemente das expressões-citação, notificação, intimação, como se tivessem um sentido identico; entretanto, a citação differe da notificação e da intimação. A citação é um chamamento a juizo; mas a notificação e a intimação não são chamamentos a juizo. A notificação é a communicação de um despacho ou mandando para fazer ou deixar de fazer alguma cousa; á intimação é a communicação de um despacho ou sentença, para que a parte se submetta ou interponha os recursos legaes. A notificação, pelo comparecimento da parte em juizo, resolve em 
(1) O intimado (2) O exequente, o executado (3) O terceiro senhor e possuidor, o terceiro prejudicado. O interessado (4) O justificante, o justificado (5) O inventarianie, o inventariado; os herdeiros, os legatarios, os credores da herança (6). O promovente, os condominos on quinhoeiros, os confrontantes ( 7 ) $\mathrm{O}$ fallido, 0 induciado, o cedente de bens (8) Os credores concurrentes (9) O embargante, o embargado (10) O aggravante, o aggravado (11)

simples citação: não quer isto dizer que a parte notificada possa, sem attentado, desobedecer o despacho ou mandado, mas que, pelo seu apparecimento em juizo, poderá oppor embargos ou defender-se contra o mesmo despacho ou mandado.

(1) Vanguerve, Pratica judicial, Parte V, cap. XIX; Pimenta Bueno, Proc. Crim., cap. V, secç. I; sentença do Supremo Tribunal de Justiça, de 16 de Março de 1861, inserto a pg. 518 da colleção Candrdo Mendes.

(2) Sentença do Supremo Tribunal de Justiça, de 15 de Setembro de 1829, de 30 de Janeiro de 1835 insertos a pg. 13 e 230 da cit. collecção.

(3) Decr. n. 9549 de 23 de Janeiro de 1886, arts. 1 a 63; Decr. n. 370 de 2 de Maio de 1890; Dec. n. 848 de 11 de Outubro de 1890, arts. 241 a 258.

(4) Souza Pinto, Processo Civil Brasileiro, §§ 204, 272, 307, 518, 519, 520, 522, 1776, 1815, 1859, 1892. Assento n. 159 de 11 de Janeiro de 1653; Pegas, a Ord. L. III, tit. I, ns. 154 e 157; Lobão, Seg. Linhas, nota 221; decr. n. 848 de 11 de Outubro de 1890, art. 385.

(5) Avisos ns. 398 de 23 de Outubro de 1872 e n. 246 de 5 de Julho de 1873. Lei n. 2033 de 20 de Setembro de 1871, art. $27 \S 2$.

(6) Ord. L. I, tit. $88 \S \S 4$ a 9; Ramalho, Inst. Orphan, pag. 174 e seguintes; Silva Pereira, Repert. das Orden. I, not. 6, pag. 123, á Ord. L. IV tit. 105; Candido Mendes. Codigo Philipino, nota 3 á cit. Ord. L. IV, tit. 105, pag. 1013; Ord. L. IV, tit. 106; Gouvea Pinto, Testamentos, cap. 33. (43x)

(7) Decr. n. 720 de 5 de Setembro de 1890.

(8) Decr. n. 72917 de 24 de Outubro de 1890.

(9) Reg. n. 737 de 25 de Novembro de 1850, arts. 605 e 638; Dec. n. 848 de 11 de Outubro de 1890, art. 318 a 331 ; dec. n. 917 de 24 de Outubro de 1890 arts. 318 a 331 ; dec. n. 917 de 24 de Outubro de 1890 arts. 318 a 331, arts. 318 a $331.46 x)$.

(10) Reg. n. 737 de 25 de Novembro de 1850, arts. 757 a 604, arts. 639, arts. 639 a 645 ; Dec. 848 de 11 de Outubro de 1890, arts. 300 a 301 , e 332 a 336 , Decr. n. 5618 de 2 de Maio de 1874, arts. 156 a 162.

(11) Dec. n. 5467 de 17 de Novembro de 1873; Reg. de 15 de Março de 1842 , arts. 19 a 24; Reg. n. 737 de 25 de Novembro de 1850, arts. 668 a 671; Dec. n. 9549 de 23 de Janeiro de 1886, arts. 53 a 58. 


\section{$O$ appellante, o appellado (1) O vencedor, $o$ vencido $(2)$}

c) $\mathrm{O}$ indiciado (3). O queixoso, o querelado (4). O denunciante, o denunciado (5) O reu solto (6) O reu affiançado, (7) $\mathrm{O}$ reu preso (8). O paciente (9)

(1) Decr. n. 54.67 de 12 de Novembro de 1873; dec. n. 848 de 11 de Out. de 1890 , arts. 43 e 337 a 349 ; Reg. n. 737 de 25 de Nov. de 1850, arts. 646 e 660 ; Dec. n. 954.9 de 23 de Janeiro de 1886, arts. 29 a 49 ; Decr. n. 4004 de 22 de novembro de 1871, arts. 59 a 62; Lei de 3 de Dezembro de 1841, aris. 78 a 86; Reg. de 31 de Janeiro de 1842 , arts. 448 a 461.

(2) Decr. n. 848 de 11 de Outubro de 1890, art. 350; Reg. n. 737 de 25 de Novembro de 1850, art. 732; Ord. L. III, tit. 67.

(3) Dec. n. 4824 de 22 de Novembro de 1871, art 29, 38 a 44, 49 a 53; Cod. de Processo, art. 134 a 148; Lei de 3 Dezembro de 1841, arts. 47 a 53; Regulamento de 31 de Janeiro de 1842, arts. 264 a 270; Dec. n. 848 de 4 de Outubro de 1890, arts. 54 a 65.

(4) Codigo Penal (Dec. n. 847 de 11 de Outubro de 1890) arts. $407 \S 1$ e 408; Codigo de Processo, arts. 72 a 80 e art. 152; Dec. n. 848 de 11 de Outubro de 1890 , art. 51 e 53.

(5) Codigo Penal, art. $407 \S 2$ e 3 ; Cod. de Processo, art. 74 a 80 e art. 152; Dec. 848 de 11 de Outubro de 1890, arts. 52 e 53.

(6) Codigo de Processo, art. $12 \S 7$; Lei de 3 de Dezembro de 1841, art. 37 e Regul. de 31 de Janeiro de 1842, art. 299 e 300; Lei n. 2033 de 20 de Setembro de 1871, art. $21 \S 3$.

(7) Codigo Penal, art. 406; Lei n. 2033 de 20 de Setembro de 1871, art. 14 dec. n. 4834 de 22 de novembro de 1871, arts. 30 a 37; Codigo de Processo, art. 102 a 112; Lei de 3 de Dezembro de 184l, art. 37, art. 38, $\S 2$ e 3, arts. 39 a 46; Reg. de 31 de Janeiro de 1842 , art. 302 a 317 . Em virtude da disposição do art. 406 \& unico, do Codigo Penal, a tabella da fiança provisoria ficou assim constituida:

\begin{tabular}{|c|c|c|c|}
\hline \multicolumn{2}{|c|}{ TERMOS } & \multicolumn{2}{|c|}{ PENAS } \\
\hline Maximo & Minimo & Prisão ceilular por menos de & Reclusão por menos de: \\
\hline $\begin{array}{l}100 \$ \\
200 \$ \\
300 \$ \\
400 \$ \\
500 \$ \\
600 \$\end{array}$ & $\begin{array}{l}1: 500 \$ \\
3: 000 \$ \\
4: 500 \$ \\
5: 000 \$ \\
6: 500 \$ \\
8: 000 \$\end{array}$ & $\begin{array}{l}\quad 9 \text { mezes } \\
1 \text { anno e } 6 \text { mez. } \\
2 \text { annos e } 6 \text { mez. } \\
3 \text { annos } \\
3 \text { annos e } 9 \text { mez. } \\
4 \text { annos. }\end{array}$ & $\begin{array}{c}2 \text { annos e } 6 \text { mezes } \\
4 \text { annos }\end{array}$ \\
\hline
\end{tabular}

(8) Cod. de Processo, art. 131 a 133; Lei n. 2033 de 30 de Setembro de 1871, art. $12 \S \S 1$ e 2 e art. 13; Decr. n. 4824 de 22 de Nov. do 1871, arts. 28 e 29.

(9) Lei n. 2033 de 20 de Setembro de 1871, art. 18; Decr. n. 4824 de 22 de Nov. de 1871, art. 75; Cod. de Proc., arts. 340 a 355; Dec. n. 848 de 11 de Outubro de 1890 , arts. 45 a 49. 
O pronunciado, o não pronunciado, o despronunciado (1) $\mathrm{O}$ recorrente, o recorrido (2) $\mathrm{O}$ absolvido, o condemnado (3) $\mathrm{O}$ indultado (4) O amnistiado (5). O rehabilitado (6)

\section{Procuradores:}

\section{a) Procurador ad negotia, procurador em causa propria, procurador judicial (7)}

(1) Cod. de Proc., arts. 14.4 a 146; Reg. de 31 de Janeiro de 1842 arts. 285, 286, 287 e 293; Lei n. 2033 de 20 de setembro de 1871, arts. 9 \&nico e 29; Decr. n. 4824 de 22 de Nov. de 1871, art. 12; Pereira e Souza, Linh. criminaes, nota 138.

(2) Lei n. 2033 de 20 de Setembro de 1871, art. 17; Dec. n. 4824 de 22 de Novembro de 1871, arts. 54 a 58.

(3) Cod. de Proc., art. 307; Reg. de 31 de Janeiro de 1842, arts. 390 e 382; Dec. n. 848 de 11 de Outubro de 1890, art 42; Cod. Penal, art. 62.

(4) Cod. Penal, arts. $71 \S 3,72 \S 2,74$ e 77.

(4) Cod. Penal, arts. $71 \S 3,72 \S 2,74$ e 77 .

(6) Cod. Penal, art. 86; Dec. n. 848 de 11 de Outubro de 1890, art. 9, n. III, $\S 2$ e 5 ; Cont. da Republica, art. 81 .

(7) Ord. L. I, tit. 48; Ord. L. III, tit. 29. Não podem ser procuradores em juizo, alem dos absolutamente incapazes, as seguintes pessoas: 1) os menores de vinte e um annos, salvo sendo graduados em direito (Ord. cit. § 28);2) as mulheres, excepto em causa propria ou na de seus paes legitimamente impedidos (Dig., de procurat, frs. 4,41 e 54); 3) os magistrados escrivães e officiaes de justiça (Ord. L. I, tit. $18 \S \S 23$ e 24; L. III, tit. $28 \S \S 2$ e 3 ; L. IV, tit. 25; Dec. de 19 de Novembro de 1722 e de 9 de Janeiro de 1723) ; 4) 0 filho, irmão, ou cunhado do juiz (Ord. L. I, tit. $43 \S 29$ ).

Os bispos, barões e viscondes com grandeza e outros titulares maiores, po. dem fazer procuração por seus secretarios, bastando somente assignal-a (Ord. L. III, tit. 29 pric. e tit. $59 \S 15$ ) ; e tambem os negociantes matriculados, podem fazel-as por seus guardas livros e escreventes, ou mesmo imprimil-a, bastando somente assignal-a (Cod. Comm. art. 21).

Em toda a procuração, alem dos nomes do constituinte e do procurador, assim como as datas do dia mez e anno, devem ser expressamente designados os poderes outorgados. O procurador não póde exceder esses poderes; e o que fizer fóra delles - é nullo. Ha casos em que o procurador não póde obrar por virtude de uma procuração geral. isto é, que precisa de especiaes poderes; e taes são: 1) Para alienar bens do constituinte 2) para transigir; 3) para jurar; 4.) para perdoar dividas; 5) para averbar suspeição; 6) para contrahir matrimonio ou requerer a nullidade delle; 7) para renuncia do beneficio ou requerer sua collação; 8) para fazer restituição in integrum, excepto sendo pedida incidentemente; 9) para seguir as appellações interpostas; 10) para receber quantias nas repartições publicas e mesmo as judicialmente demandadas; 11) para substabelecer; 12) para confessar; 13) para hypothecar. (Sousa Prnto, Processo Civil Brasileiro, § 177 e 179; Pimenta Bueno, Apontam. civis, tit. II, cap. III, sec. II § 3; Teixeira de Freitas, Form. cit. § 599 e Consol. das Leis Civis, art. 470).

Finda o mandato do procurador: 1) pelo mutuo dissenso; 2) proferida a sentença definitiva (Ord. L. III, tit. 27, princ.), podendo poréin interpor appel. 


\section{b) Advogado (1) Solicitador (2) Defensor (3). Excusador (4) \\ 3. Tutores (5): \\ a) Tutores como representantes (6) \\ b) Tutores como assistentes (7)}

\section{Curadores:}
a) Curadores representantes (8)
b) Curadores assistentes (9)
c) Curadores á lide (10)

lação sem que fique habilitado para seguil-a; 3) pela morte do constituinte (Ord. L. III, tit. $27 \S 2)$; 4) pela morte do procurador; 5) pela renuncia voluntaria do procurador, feita com justa causa (Ord. L. III, tit. 26, princ. e §11) ; 6) pela revogação da procuração (Ord. L. III. tit. 26, princ.) excepto se a procuração é em causa propria (Ramalho, Praxe Bras. § 61) Vide Reg. 737 de 25 de Novembro de 1860 , art. 706.

O Dec. n. 79 de 23 de Agosto de 1892, determina que todas as pessoas habilitadas para a vida civil podem passar procuração do proprio punho.

(1) Ord. L. I, tit. 48 e outras leis citadas na nota 286 de Souza Pinto. Proc. civil brasil.; Cit. Souza Pinto, $\$ \S 100$ a 115; assentos de 16 de Maio de 16:0, de 2 de Maio de 1654, de 11 de Fevereiro de 1658, de 24 de Março de 1672 e de 11 de Agosto de 1685; Reg. de 15 de Março de 1874 art. 25; Dec. n. 5618 de 2 de Maio de 1874, arts. 43 a 48 ; Dec. n. 764 de 19 de Setembro de 1890; Dec. n. 5737 de 2 de setembro de 1374, art. 202; Aviso de 16 de Janeiro de 1838; Reg. n. 737 de 25 de Novembro de 1850, arts. 703 a 718 ; Dec. n. 848 de 11 de Outubro de 1890 , art. 372 a 379 .

(2) Souza Pinto; Proc. Civil Bras., §§ 183 a 194; Dec. n. 5618 de 2 de Maio de 1874, arts. 47 e 48; Decr. n. 5737 de 2 de Setembro de 1874, arts. 88 e 89; Reg. n. 737 de 25 de Novembro de 1850, arts. 704 e 705.

(3) Ord. L. I, tit. 92, §10; cit. Souza Prnтo, §\$195 a 197.

(4) Ord. L. III, tit. $20 \S 3$; cit. Souza Pinto, $\S \S 198$ a 201 Vanguerve, Prat. Judicial, part. II, cap. 29, n. 13; Lobão, Seg. linhas, notas 171 e 172.

(5) Ord. L. IV, tit. 102 e 104 e L. I, tit. 88 33; Teixeira de Freitas, Cons. das leis civis, art. 238 a 310 .

(6) Ord. L. III, tit. $29 \S 1$, tit. $41 \S 8$ e tit. 63; Terxerra de Freitas, Cons. das leis civis, art. 25, nota 30 .

(7) Ords. citadas; Teixeira de Freitas, ci., art. 26, nota 31; Pimenta Bueno. Apont. scbre o Proc. Civel, §54.

(8) Ord. L. IV, tit. 103, Ord. L. I, tit. 90 princ.; Reg, i, 834 de 2 de Outubro de 1851, art. 48; Reg. n. 2433 de 15 de Junho de 1859, art. 20 e segs. TerxeIra de Freitas, arts. 29 a 34.

(9) Ord. L. III, tit. $29 \S 1$ e tit. $41 \$ 8$.

(10) Ord. L. III, tit. 41 Prmenta Bueno, obra cit. $\S \S 58$ e 59; Dec. n. 764 de 19 de Setembro de 1890; Sentença do Supremo Tribunal de Justiça de 4 de Dezembro de 1832, na collect. cit.; Silva, a Ord. L. III, tit, 61 §, n. 1. 
5. Testamenteiros:

a) Testamenteiros nomeados pelo testador (1)

b) Testamenteiros nomeados pelo juiz (2)

6. Syndicos:

a) Syndicos representantes de pessoas juridicas (3)

b) Syndicos de massas fallidas (4).

II. Orgams do ministerio publico.

1 Na justiça Federal (5)

a) Procurador geral da Republica

b) Procurador seccional.

2. Na justiça do Districto Federal (6).

a) Procurador geral do districto

b) Sub-procurador geral.

c) Curador de Orphãos, curador de ausentes, curador de residuos, curador de massas fallidas.

d) Promotores publicos e adjunctos.

3. Na justiça dos Estados.

a) Promotor de Justiça ou Procurador Geral do Estado (7)

(1) Ord. L. I, tit. 62; Lei de 27 de Agosto de 1830; Dec. n. 834 de 2 de outubro de 1851; Teixeira de Freitas, Cons. cit., arts. 1086 a 1140.

(2) Ords. e leis cits.; Terxerra de Freitas, Cons cit., nota 3 ao art. 1232.

(3) Ord. L. I, tit. $62 \S \S 39$ a 66. Teixeira de Freitas, Con. cit. art. 463 :

(4) Decr. n. 917 de 24 de Outubro de 1890 , art. 6 \ unico, letra $c$, arts. 36 e seguintes.

(5) Decr. n. 848 de 11 de Outubro de 1890 , arts. 21 a 26.

(6) Decr. n. 1030 de 14 de Novembro de 1890 , arts. 23 a 25 e 165 a 180

(7) Decr. n. 5618 de 2 de Maio de 1874, arts. 17 a 23. 
b) Curadores de orphãos e ausentes $e$ promotores de residuos em cada comarca (1).

c) Promotor publico em cada Comarca (2)

III. Juizes :

a) Juiz singular. Juizes Collectivos ou tribunal. Jurados e vogaes. Juizes arbitros. Auctoridades policiaes.

b) Quadro da organisação judiciaria federal (3)

c) Quadro de organisação judiciaria e policial do districto federal (4)

d) Quadro da organisação judiciaria e policial dos Estados (5).

IV Serventuarios da Justiça (6)

1. Tabellião de notas (7) Official do Registro Geral (8). Official de protes-

(1) Decr. n. 9420 de 28 de Abril de 1885, arts. 92 a 98; Ord. L. I, tit. 64; Decr. n. 834 de 2 de Outubro de 1851; Ferreira Alves, Cons. das leis da Provedoria $\$ 252$ e 454; Decr. n. 2433 de 15 de Junho de 1859.

(2) Lei n. 2033 de 20 de Setembro de 1871, art. 16; Decr. n. 4824 de 22 de Novembro de 1871, arts. 20 a 23; Cod. de proc., arts. 36 e 37; lei de 3 de Dezembro de 1841, arts. 22 e 23; Reg. de 31 de Janeiro de 1842, arts. 213 a 222.

(3) Dec. n. 848 de 11 de Outubro de 1890.

(4) Decr. n. 1030 de 14 de Novembro de 1890.

(5) A organisação do tempo do Imperio estava nas seguintes leis $e$ Decretos: Decr. n. 5618 de 2 de Maio de 1874; Lei n. 2033 de 20 de Dezembro de 1841; Reg. n. 120 de 31 de Janeiro de 1842; Reg. de 15 de Março de 1842.

(6) Decr. n. 9420 de 28 de Abril de 1885; Tavares Bastos, Empregos e Officios de Justiça.

(7) Ord. L. I, tits. 78 e 80; Assentos de 17 de Agosto de 1811 e 10 de Junho de 1817; Decr. n. 4824 de 22 de Nov. de 1871, art. 78; cit. Decr. n. 9420 de 28 de Abril de 1885, art. 88.

(8) Decr. n. 169 A de 19 de Janeiro de 1890; Decr. n. 370 de 2 de Maio de 1890, arts. 6 a 10 ; Decr. n. 544 de 5 de Julho de 1890. 
tos (1). Escreventes juramentados, officiaes ajudantes. Officiaes do Registro de Titulos e Documentos.

2. Escrivães:

A) $\mathrm{Na}$ justiça federal (2):

a) Secretario do Supremo Tribunal Federal, servindo tambem de escrivão ;

b) Dous escrivães no Districto Federal e nos Estados de S. Paulo, Minas Geraes e Pernambuco.।

c) Um escrivão nos outros Estados.

B) No Districto Federal: (3)

a) Escrivães da Corte de Appellação;

b) Escrivães no Tribunal civil e criminal;

c) Escrivães do Jury;

d) Escrivão do Juizo da Fazenda Municipal,

e) E escrivães de pretorias;

f) Escreventes juramentados, ajudantes, fieis de cartorio.

c) Nos Estados (4):

a) Escrivães do civel e crime;

b) Escrivães de orphãos e ausentes;

(1) Decr. n. 5557 de 20 de Fevereiro de 1874; cit. Decr. n. 9420 de 28 de Abril de 1885, art. 38 e 88; Aviso n. 127 de 25 de Maio de 1859.

(2) Decr. n. 847 de 11 de Outubro de 1890 , arts. 27 a 32.

(3) Decr. n. 1030 de 14 de Nov. de 1890, arts. 187 a 196.

(4) A organisação antiga acha-se nas Ords. L. I, tits. 50, 79, 80 e 89; Cod. de Proc., arts. 39 e 40; Lei de 3 de Dezembro de 184.1, art. 108; Lei de 3 de Novembro de 1830; Regul. n. 2433 de 15 de Junho de 1859, art. 76; cit. Decr. n. 5618 de 2 de Maio de 1874, arts. 35 a 42; cit. Decr. n. 9420 de 28 de Abril de 1885. 
c) Escrivães da provedoria de residuos;

d) Escrivães do Jury e execuções criminaes;

e) Escrivães do juizo de Casamento, nas capitaes;

f) Escrivães dos feitos da Fazenda do Estado, nas capitaes,

g) Escrivães de policia,

h) Escrivães do Juizo de Paz;

i) Escrivães de appellações;

j) Escreventes juramentados, ajudantes, fieis de cartorio.

3. Outros serventuarios da Justiça:

A) $\mathrm{Na}$ justiça federal (1).

a) Continuos e officiaes de Justiça;

b) Porteiros.

B) No Districto Federal (2)

a) Distribuidor

b) Contadores

c) Partidores

d) Porteiros dos Tribunaes

e) Porteiro do Jury

f) Porteiro dos auditorios

g) Officiaes de Justiça

C) Nos Estados (3)

a) Distribuidores

b) Contadores

c) Partidores

(1) Cit. Decr. n. 848 de 11 de Outubro de 1890, arts. 30, 31, 32. 218.

(2) Cit. Decr. n. 1030 de 14 de Novembro de 1890, arts. 197, 216, 217

(3) Cit. Decr. n. 9420 de 28 de Abril de 1885. 

d) Officiaes de Justiça
e) Porteiro do Tribunal
f) Porteiros dos auditorios.
g) Depositarios, thesoureiros
h) Carcereiros (1)

4. Empregados das Secretarias dos Tribunaes:

A) No Supremo Tribunal Federal (2):
a) Secretario
b) Officiaes
c) Amanuenses
d) Continuos
e) Porteiro

B) No Districto Federal, em cada um dos Tribunaes (3)
a) Secretario
b) Amanuenses
c) Continuos
d) Porteiro

C) Nos Estados, no Tribunal de Justiça ou Relação (4):
a) Secretario
b) Amanuenses
c) Continuos
d) Officiaes de Justiça
e) Porteiro.

(1) Regul. n. 120 de 31 de Janeiro de 1842, art. 144 a 170; Decr. n. 5737 de 2 de Setembro de 1874, art. 194; Decr. n. 4824 de 22 de Novembro de 1871 , art. 75 .

(2) Cit. Decr. n. 848 de 11 de Outubro de 1890 , arts. 27 a 30.

(3) Cit. Decr. n. 1030 de 14 de Nov. de 1890, arts. 181 a 186.

(4) Cit. n. 5610 de 2 de Maio de 1874, arts. 24 a 34. 


\section{Auxiliares do Juizo na verificação e apreciação dos objectos presentes: \\ 1. Arbitradores (1) \\ 2. Peritos (2) \\ 3. Avaliadores (3)}

VI. Testemunhas.

\section{Nos contractos (4) \\ 2. Nos testamentos e disposições causa mortis (5).}

(1) Reg. n. 737 de 25 de Novembro de 1850, arts. 189 a 205; Ord. L. III tit. 17; Dec. n. 720 de 5 de Setembro de 1890, arts. 23 a 31 e 70; Reg. de 21 de Outubro de 1754; Alvará de 21 de Junho de 1759; Lei de 21 de Janeiro de 1759; Leis de 11 de Outubro de 1773 e 20 de Junho de 1774.

(2) Leis e Regul. supra citados; Reg. n. 737 de 25 de Novembro de 1850 arts. 209 a 215; Reg. n. 120 de 31 de Janeiro de 1842, arts. 258 a 261.

(3) Leis e Regul. supra citados; Reg. n. 737 de 25 de Novembro de 1850, arts. 532 a 537; Dec. n. 370 de 2 de Maio de 1890, art. 392.

(4) Nos contractos e escripturas dos contractos as testemunhas devem ser pelo menos duas (Ord. L. I, tit. 78 §4). As nossas leis são silenciosas sobre a capacidade civil das testemunhas dos contractos e escripturas dos contractos; mas a praxe tem firmado que o tabellião não deve admittir como testemunhas: 1) os impuberes, os alienados, os prodigos interdictos; 2) os surdos, os mudos, os cegos; 3) Os analphabetos; 4) as mulheres; 5) os estrangeiros que não ntendem a lingua portugueza. Estas incapacidades são enumeradas em Terxeira de Freitas, Form. do tabellionato, pag. 143; Ferrão, Guia Pratica, pag. ; MAchado, Guia Pratica, pag. 83 e 84 . Este ultimo entende que os menores de 21 annos não podem ser testemunhas nas escripturas, mas esta opinião é sem fundamento; realmente, se a lei (Ord. L. IV, tit. 80) exige, para o testamento, que astestemunhas sejam maiores de 14 annos, qual a razão porque, para os contractos deverão ellas ser maiores de 21. Convem entretanto notar, que o Decr. de 7 de Março de 1888, em relação aos assentos do Registro Civil, exige, no art. 13, que as testemunhas para taes assentos deverão ser, sempre que for possivel, varões e maiores de 21 annos, nunca porem, se admittirão como testemunhas os menores de 14 annos.

Alguns praxistas entendem que não ha razão para que os prodigos sejam excluidos da capacidade testemunhal nos contractos; e esta opinião tende a prevalecer.

Tambem não podem ser testemunhas por suspeição clarissima: 1) Os (lescendentes, ascendentes e irmãos do tabellião; 2) o marido no negocio damulher; 3) os ascendentes no negocio dos descendentes e vice-versa; 4) o sogro e sogra nos negocios de genro e nora e vice versa (cit. MaCHado, pag. 84.).

(5) Neste ponto é terminante a Ord. L. IV, tit. 80. Assim nos testamentos abertos publicos (Ord. cit. princ.) assim como nos instrumentos de approvação do testamento cerrado (Ord. cit. $\$ \$ 1$ e 2), é essencial o numero de cinco testemunhas, varôes livres e puberes. No testamento privado aberto (Ord. cit. 83), é essencial que, contado o testador ou a pessoa privada que por sels 


\section{No processo civel e commercial (1).}

\section{No processo criminal (2)}

rogo fizer o testamento, assistam e assignem seis testemunhas. No tesiamento nuncupativo (Ord. cit. §4), é essencial o numero de seis testemunhas. A praxe tem estabelecido que em todıs as escripturas de disposições causa mortis, é essencial o numero de cinco testemunhas. $\Lambda$ Ord. L. IV, tit. 85, determina as pessoas que não podem ser testemunhas em testamentos e são: o varão menor de 14 annos, a femea menor de 12, alienado ou furioso, o mudo o surdo, o cego, o prodigo interdicto, o herdeiro e seus ascendentes e descendentes e irmãos do herdeiro que estiverem em poder do pae. O legatario, pode ser testemunha no testamento em que lhe forem deixados alguns legados (Ord. cit. § 1) Nos codicillos bastam quatro testemunhas, puberes, homens ou mulheres, e até tres nos logares de pequena povoação. (Ord. L. IV, tit. 86).

Para o casamento in extremis (caso do art. 37 de Decr. n. 181 de 24 de Janeiro de 1890) são necessarias seis testemunhas, maiores de 18 annos e que não sejam parentes do enfermo no gráo prohibido, que não o sejam mais delle do que do outro contrahente. No caso de molestia grave de um dos contrahentes, o juiz irá á casa do impedido, e lá, nos termos do art. 34, alem das suas do acto, assistirão mais duas maiores de 18 annos e que saibam ler e escrever.

(1) As testemunhas no processo civel e commercial, devem ser juramentadas conforme a religiáo de cada uma, excepto se forem de tal seita que prohiba o juramento (Reg. n. 737 de 25 de Novembro de 1850, art. 175). Devem declarar seus nomes, pronomes, idades, estado, domicilio ou residencia, si são parentes, em que gráo, anigos, inimigos ou dependentes de alguma das partes (Reg. cit., art. 176); é a estas declarações relativas ao parentesco, amizade ou inimizade e dependencia - que a Ord. L. I, tit. 86, denomina - costume. No processo da justiça federal, não podem ser testemunhas: o ascendente, marido, mulher, consaguineo ou affim até o $2 .^{\circ}$ grau por direito civil e o menor de 14 annos (Decr. n. 848 de 11 de Outubro de 1890, art. 171. As testemunhas devem depor sobre os factos allegados e suas circumstancias ('Ord: LI tit. $86 \$ 1$ ). Por via de regra, duas testemunhas contestes fazem prova plena; a respeito de cada artigo não podem ser dadas mais de quinze testemunhas podendo chegar até o numero de vinte, sendo um só artigo ou estando allegado factos diversos (Ord. L. III, tit. 55 §2). As testemunhas devem dar a razão de sua sciencia do facto e das circunstancias concomitantes: quando disserem que os sabem de vista, devem tambem dizer em que tempo e lugar os foram e se estavam ahi outras pessoas que tambem os vissem; e se disserem que o sabem de ouvida, devem tambem dizer a quem os ouviram e em que tempo ou lugar, assim como as pessoas que tambem ouviram (Ord. L. I, tit. $86 \S 1)$.

Ha casos em que podem ser testemunhas os parentes dos contractantes e litigantes: taes são as testemunhas do casamento civil (art. 24 do Decr. n. 181 de 24. de Janeiro de 1891), nas justificações de idade, de estado, etc.

(2) Nos processos policial e criminal não podem ser testemunhas: 0 «scendente, o descendente, marido e mulher, parente até o segundo gráo e o menor 
- Vejamos, agora, quaes são as cautelas de que se devem prevenir estes agentes para que a sua força tenha a necessaria efficacia.

I. Quanto ás partes, seus representantes e assistentes:

1. Quanto ás partes.

a) Cautelas relativas á identidade pessoal e a capacidade de facto.

b) Cautelas relativas á capacidade de direito.

c) Cautelas relativas á responsabilidade criminal.

2. Quanto aos procuradores:

a) Cautelas relativas á capacidade de facto e de direito.

b) Cautelas relativas a legitimidade e regularidade do mandato.

3. Quanto aos tutores e curadores, testamenteiros e syndicos:

a) Cautelas relativas á legitimidade da nomeação e á capacidade juridica dos nomeados;

de 14 annos; mas a autoridade ou o juiz poderá informar-se delles sobre o objecto da queixa ou denuncia e reduzir a termo a informação, que será assignada pelos informantes a quem se não se deferirá juramento (cod. de Proc., art. 89). No inquerito policial poderão ser inquiridas todas as testemunhas que houverem presenciado o facto ou tiverem razão de sabel-o (Decr. n. 4824 de 22 de Novembro de 1871 , art. 39 \$3) No summario a que se proceder para a formação da culpa, nos casos em que não tem logar o procedimento ex-officío, inquirir-se-ão pelo menos duas testemunhas e poderão ser inquiridas mais até o numero de cinco. Nos casos porem em que tiver lugar a denuncia, inquirir-se-ão cinco, e poderão ser inquiridas mais até o numero de oito. Alem do numero das testemunhas, tanto $\mathrm{cm}$ um como em outro caso, serão inquiridas, sempre que for possivel, as pessoas referidas pelas testemunhas, que já houverem deposto, assim como informantes (Lei ie 3 de dezembro de 1841, art. 48; Reg. n. 120 de 31 de Janeiro de 1842, arts. 266 a 268). No plenario as testemunhas deverão ser apresentadas em rol pelo accusador e pelo réo, para serem por elles chamados, e ahi não ha limite legal para o numerc dellas (Reg. cit., art. 355 a 357). 
b) Cautelas relativas ás condições para o exercicio;

c) Cautelas relativas aos casos de representação e acs casos de assistencia;

d) Cautelas relativas á suspeição e remoção.

1I. Quanto aos orgams do Ministro Publico.

a) Cautelas relativas á legitimidacie da Nomeação e á capacidade juridica dos nomeados;

b) Cautelas relativas ás condições do exercicio,

c) Cautelas relativas ás attribuições;

d) Cautelas relativas ás substituições;

III. Quanto aos juizes e autoridades policiaes:

a) Cautelas relativas á suspeição (1),

b) Cautelas relativas á legitimidade jurisdiccional, districto de jurisdicção; instancia (2) ;

(1) Dec. n. 848 de 11 de Outubro, art. 133; Reg. n. 737 de 25 de Novembro de 1850, art. 86; Cod. de Processo, arts. 61 a 71; Reg. de 31 de Janeiro de 1842 , arts. 247 a 255.

(2) Nenhum juiz ou tribunal póde exercer jurisdicção fóra do districto territorial onde se acha investido de autoridade, salvo nos casos de prorogação determinados em lei. A jurisdicção é federal ou estadual, civel ou criminal, inferior ou superior: a primeira distincção caracteriza-se pela materia se a da união ou dos Estados; a segunda caracterisa-se pela natureza civel ou penal do direito violado; a terceira caracterisa-se pela instancia, isto é, pela graduação do juiz ou tribunal que conhece do pedido. A instancia começa pela citação, termina pela sentença, e suspende-se: 1) pela morte de algum dos litigantes (Ord. L. III, tit. 27 \$2); pelo lapso de tempo, estando o feito parado por mais de seis mezes sem se fallar a elle, ou estando concluso um anno na mão do escrivão (Ord. L. tit. 84 \& 28 e LIII, tit. $1 \S 15$ ). Diz-se a instancia perempta, quando o réo é della absolvido; e então renova-se a citação para o réo novamente fallar á mesma acção, salvo no caso de tres absolviçōes caso este em que fica perempta não só a instancia, como a acção (Ord. L. III tit. 14). Quando a instancia está suspensa pelo lapso de tempo, é necessaria nova citação para que ella prosiga; e quando o está pela morte de algumas das partes deve haver habilitação de herdeiros (Ord. L. III tit. 82 , princ.). 


\section{c) Cautelas relativas á competencia e á prevenção; vara, alçada, substi- tuições (1),
d) Cautrelas relativas á revisão e sorteio dos jurados e vogaes (2),

(1) A competencia da justiça federal está determinada na Constituição da Republica, arts. 59 a 62; e no Dec. n. 848 de 11 de Outubro de 1890, no art. 9; quanto ao Supremo Tribunal Federal; e no art. 15, quanto aos juizes de Seç̧ão. $\mathrm{Na}$ justiça local ou estadoal, a competencia civil geral determina-se pelo domicilio da parte citada ou notificada; a competencia civel especial determina-se ou em razão das pessoas, ou em razão das cousas, ou em razão de certos factos. A competencia especial em razão das pessoas attende: 1) as pessoas dos commerciantes ou a actos que podem affectar-lhes de qualquer modo, isto é, juizo commercial (Reg. n. 737 de 1850, arts. 6 a 22) 2) as pessoas de orphãos e ausentes, juizo de orphãos (Reg. n. de 15 de Março de 1842, arts. 4 a 7, etc) ; 3) as pessoas dos testadores e as pessoas juridicas de interesse publico a juizo da provedoria (Ord. L. I, tit. 50 a 52, Reg. de 2 de Outubro de 1851, etc.) 4.) á pessoa juridica-Estado-ou juizo da Fazenda Municipal. A competencia especial em razão da cousa, determina-se unicamente pela situação da cousa demandada, foro rei sitae (Ord. L. III, tit. $5 \$ 12$, tit. $11 \S \S 5$ e 6 e tit. $45 \S 10$; Decr. n. 720 de 5 de Setembro de 1890, arts. 19 e 20). A competencia especial em razão dos factos determina-se: ou pelo contracto (Ord. L. III, tit. $6 \S 3$ e tit. 11 §3) ou pela connexão do negocio MoRAES DE Carvalho, Praxe forense §45), ou pela prorogação da jurisdiç̧ão (Ord. L. III tit. 49 §2; Decr. n. 763 de 19 de Setembro de 1890 , arts. 2 e 3, e etc. Teixerra de Freitas, nota 56 a Pereira de Souza) ou pelo delicto. (Ord. de Processo, art. 160: reg. n. 120 de 31 de Janeiro de 1842, arts. 241 a 246; Decr. n. 4824 de 22 de Nov. de 1891, arts. 10 a 19, Dec. n. 5018 de 2 de Maio de 1874, art. $10 \$ 1$ n. 1 e $\$ 2$ n. 1. A prevenção é a competencia do juiz em causa de que tomou conhecimento antes de outro juiz igualmente competente (TeIXeIra de Freiras, cit. nota 58; Moraes de Carvalho cit. § 51).

A competencia geral é limitada pela alçada do juiz; a competencia especial é limitada pela alçada e pela vara. Alçada é a quantia alem da qual não póde - juiz julgar ou dentro da qual não se admitte recurso algum Vara era a insignia dos juizes e autoridades; as varas diversificavam na côr e em outras particularidades; assim os juizes ordinarios tinham varas vermelhas e os juizes de fóra varas brancas. (Ord. L. L. tit. $65 \S 1$ ); hoje, por metonymia, se emprega a expressão vara para significar a competencia especial de cada juiz.

Quanto as substituiçôes: $\mathrm{Na}$ justiça federal, regulam os arts. 7, 11, 12 letra g, 18, 19 e 20 do Decr. 848 de 11 de Outubro de 1890, quanto ás justiças nos Estados, regulam no Districto Federal os arts. 52, 54, 57, 58, 82 n. 2 e §2, 86, 117,118 e 135 e nos Estados onde ainda não ha nova organisação judiciaria pelo Decr. n. 4824 de 22 de Nov. de 1871, arts. 3. 6, 7 e pelo Decr. n. 5618 de 2 de Maio de 1874, arts. 7 e 8.

(2) Dec. n. 848 de 11 de Outubro de 1890, art. 41; Dec. n. 1030 de 14 de Novembro de 1890, arts. 41 a 46 e 110 a 118; Reg. de 31 de Janeiro de 1842, arts. 223 a 255 e arts. 326 a 336 . 
e) Cautelas relativas ás condições de exercicio (1) tiça :

IV Quanto aos serventuarios e empregados da Jus-

a) Cautelas relativas á legitimidade dos provimentos ou da substituição e á capacidade juridica dos providos ou substitutos; districto do officio.

b) Cautelas relativas ás condições do exercicio.

c) Cautelas relativas á suspeição.

d) Cautelas relativas ás attribuições.

V. Quanto aos auxiliares do Juizo:

a) Cautelas relativas á legitimidade da nomeação ou louvação e a capacidade juridica dos nomeados ou louvados, substituições,

b) Cautelas relativas ás condições do exercicio;

c) Cautelas relativas ás attribuições;

d) Cautelas relativas á suspeição.

VI. Quanto ás testemunhas:

c) Cautelas relativas á capacidade juridica e ao numero das testemunhas dos contractos,

b) Cautelas relativas á capacidade e ao numero das testemunhas dos testamentos e disposições causa mortis;

c) Cautelas relativas a capacidade juridica e ao numero das testemunhas nos autos e termos judiciaes;

d) Cautelas relativas ás testemunhas inquiridas nos processos: capaci-

(1) Diploma ou titulo de nomeação, compromisso e posse. 
dade juridica e numero dellas em cada especie de processo; costumes; perguntas e respostas; razão dos ditos ou respostas; reperguntas; careação e confrontação; contestação e sustentação. Informantes (1).

- A efficacia da força que estes agentes empregarem, dependerá tambem do modo por que se dispuzerem para o movimento no tempo e no espaço. Consideraremos, pois, especialmente sob este ponto de vista, em primeiro logar as cautelas relativas ao movimento no espaço:

1. Cautelas relativas ao domicilio das partes, seus procuradores, tutores e curadores, testamenteiros e syndicos (2)

2. Cautelas relativas ao districto da jurisdicção dos juizes e autoridades policiaes, ás varas cumulativas, ao auditorio ou tribunal onde funccionam (3);

(1) No processo civil e commercial, as testemunhas serão perguntadas ou reperguntadas somente sobre os factos allegados na acção, contestação, replica e treplica e suas circunstancias; e serão pelas proprias partes que as produzirem ou por seus advogados ou procuradores e reperguntadas e contestadas pelas parte contraria ou por seus advogados e procuradores; os depoimentos serão escriptos pelo escrivão e rubricados pelo juiz, sendo-lhe licito fazer ás testemunhas as perguntas que julgar opportunas (Dec. n. 848 de 11 de Outubro de 1890, arts. 173 a 175; Reg. n. 737 de 1850, arts. 179 e 181). No processo policial e no criminal é a autoridade ou o juiz quem faz as perguntas á testemunha, não podendo, porem, o juiz, no summario de culpa, recusar ás partes quaesquer perguntas ás testemunhas excepto se não tiverem relação alguma com a exposição feita na queixa ou denuncia; devendo, porem, ficar consignadas no termo de inquirição a pergunta da parte e a recusa do juiz (Reg. n. 4824 de 22 de Nov. de 1871, art. 52) ; no plenario, as proprias partes e os juizes fazem as perguntas e reperguntas. Quanto á careação e confrontação, vide arts. 96 e 97 do Cod. de Proc.

(2) Teixeira de Freitas, nota 43 a Pereira e Souza.

(3) Auditorio, logar onde o juiz costuma despachar e a dar audiencia ás partes. Audiencia é o lugar e o tempo destinado para o juiz ouvir pessoalmente as partes ou seus procuradores, deferir seus requerimentos, proferir decisóes sobre questões de facil solução e publicar despachos e sentenças. Tribunal é o lugar onde se reunem os juizes collectivos, para ouvirem as partes nos casos legaes discutirem e votarem sobre o processo e recursos que lhes são affectos. IO tempo destinado a isso denomina-se sessão ou conferencia. As audiencias e as sessões podem ser ordinarias e extraordinarias e especiaes: ordinarias, quando occorrem nos dias e horas determinados para o curso normal dos processos; extraordinarias ou especiaes, quando occorrem em dias e horas especialmente designadas para certa ordem de actos processuaes. 
3. Cautelas relativas ao auditorio ou Tribunal perante os quaes funccionam os orgams do ministerio publico.

4. Cautelas relativas ao districto do officio dos serventuarios de justiça; aos juizes e tribunaes perante os quaes funccionam os escrivães; aos officios privativos e aos officios cumulativos; aos cartorios onde funccionam os serventuarios e ás repartições: onde funccionam os empregados da justiça (1),

5. Cautelas relativas aos lugares onde os auxiliares do juizo terão de apreciar os objectos e factos que lhe forem presentes.

6. Cautelas relativas aos cartorios e aos auditorios, onde as testemunhas, rogadas ou citadas, terão de comparecer para assistirem o facto presente ou deporem sobre o facto preterito.

Passemos agora a apontar as cautelas relativas ao movimento no tempo.

1. Cautelas relativas ao tempo do trabalho forense: dia natural, dia civil (2) Ferias; ferias de Natal, ferias de Semana Santa, dias feriados; serventuarios que não gozam das ferias (3)

2. Cautelas relativas aos periodos de tempo e partes successivas do movimento

(1) Cartorio é o lugar onde trabalham os serventuarios da justiça e onde elles tem o seu archivo. Escriptorio é o lugar onde trabalham os advogados e os solicitadores.

(2) Dia natural é o tempo de luz determinado pelo nascer e pôr do sol. e neste sentido oppõe-se a noute; dia civil é o tempo de vinte e quatro horas. Nenhum acto extrajudicial, salvo testamentos e codicillos, assim como nenhum acto judicial, salvo casos de urgencia, podem ser feitos antes que o sol saia ou depois que se puzer (Or. L. III, tit. 1 \$16) Barbosa e Pegas, nos respectivos comment.); mas uma vez começado antes do sol posto, deve acabar mesmo á noute.

(3) Decr. n. 67 de 18 de Dezembro de 1889; Dec. n. 1285 de $30 \mathrm{~d} \epsilon$, Novembro de 1853. 
forense: Prazos convencionaes, prazos legaes, prazos judiciaes (1) ; termos dilatorios ou dilações; termos comminatorios, termos peremptorios, termos fataes (2), Prazos continuos, prazos interrompidos, prazos que correm de momento a momento (3). Cautelas relativas ao modo de contar o tempo para effeitos juridicos: dies a quo, dies ad quem (4). Tempo para a transcripção, inscripção, e averbação no Registro geral (5).

(1) Praso convencional, quando é fixado pelas partes nos contractos e testamentos; praso legal, quando é fixado pela lei; praso judicial, quando é assignado, pelo juiz. Estas duas ultimas especies de prazos tomam, no processo, a denominação de termos.

(2) Os tenmos dilatorios são estabelecidos para que certos actos não se possam effectuar antes delles, isto é, para que não se possam effectuar senão depois delles assignados, ex. da produç̧ão de provas no processo. Os termos comminatorios são estabelecidos para que certos actos se effectuem antes de expirado um prazo previamente fixado; ex. o termo de quinze dias para, antes de expirados, o arrestante ou embargante propor a acção competente (Reg. 737 de 1850, art. 332 $\$ 2$. Os termos peremptorios são estabelecidos por motivos de ordem publica, para dentro delles encerrar-se definitivamente actos processuaes; ex. todos os termos que os juizes assignarem ás partes ou a seus procuradores visto que, por expressa disposição da Ord. L. III, tit. $20 § 44$, esses termos assim assignados, são havidos por peremptorios "sem os julgadores os poderem reformar". Os termos fataes são os marcados para a interposição e seguimento dos recursos: o periodo de tempo contido nestes termos fataes é continuo, corre de momento a momento, não se interrompe pela superviniencia das ferias (Ord. L. III, tit. 70; Reg. n. 5467 de 12 de Novembro de 1873; Reg. de 15 de Março de 1842; Decr. n. 9549 de 23 de Jan. de 1886 , arts. 30 e seguintes, arts. 53 a 58 ; seg. n. 120 de 31 de Janeiro de 1842, art. 442; Lei de 3 de Dez. de 1841, arts. $79 \$ 1$ e Reg. cit. art. 451 Dec. n 4824 de 22 de Nov. de 1871, arts. 54 a 62) Vide Moraes Carvalho, praxe Forense, nota 220 .

(3) Prazos continuos são os que não se interrompem por ferias ou por algum outro impedimento; prazos interrompidos são aquelles em que não se contam os dias feriados ou impedidos; prazos que correm de momento a momento são os que se contam desde a hora em que principiaram (Ord. L. III, tit. 70, etc.) Exceptuados os termos fataes todos os outros se interrompem pelas ferias, quando estas abrangem mais de metade do prazo.

Comm. art. 356

(4) Ord. L. III, tit. 13 - Die a quo non computatur in.termino. Cod.

(5) O numero de ordem do Protocollo de Registro Geral determina a prioridade do titulo, ainda que os outros titulos sejam por alguma razão especial anteriormente registrados. Quando duas ou mais pessoas concorrerem ao mesmo tempo, os titulos apresentados terão o mesmo numero de ordem. O mesmo tempo quem dizer de manhã, das 6 á 1 hora e de tarde, das 12 ás 16 horas (Dec. n. 370 de 2 de Maio de 1890 . arts. 43,44 e 45). 
3. Cautelas relativas ao tempo correspondentemente ao logar dos trabalhos processuaes. Audiencia, sessão ou conferencia; sessão ordinaria, sessão extraordinaria, sessão especial. Dia, hora e logar das sessões e audiencias, disposição dos assentos e precedencias (1).

E como a efficacia da força da causa efficiente está, ¿lluitas vezes, subordinada a certas circunstancias e exigencias legaes relativas ao movimento fóra dos auditorios, cartorios, e escriptorios, ou fóra do dia natural e dentro das ferias - ha tambem a considerar:

Cautelas relativas ao movimento que, no fôro extrajudicial, se denominam - estadas -, e no fôro judicial-diligencias (2)

Estas cautelas, assim como as relativas aos movimentos que podem exceder os limites do dia civil e ser feitos em. ferias, serão melhor apreciadas quando tratarmos das relações entre a causa efficiente e a causa material da actividade forense.

\section{CAPITULO III}

SUMMARIO - Causa material da actividade forense-Contractos, testamentos, e registros - Actos processuaes e acções - Leis e PraxeCautelas.

A causa material da actividade forense póde ser apreciada debaixo de tres aspectos - A materia principio passivo do acto forense, consiste no facto já revestido de sua forma de acto juridico; ou antes, o facto, o direito funda-

(1) Decr. n. 4824 de 22 de Novembro de 1871, art. 77; Ord. L. III, tit. 19; Cod. de Processo, arts. 59 a 60; Reg. n. 120 de 31 de Janeiro de 7842, arts. 195 e 196; Dec. n. 848 de 11 de Outubro de 1890, arts. 364, 467 e 368; Dec. n. 5618 de 2 de Maio de 1874 , arts. 49 a 80 .

(2) Ord. L. I, tit. 78 §3; Ord. L. I, tit. $79 \S 9$; Decr. n. 5737 de 2 de Setembro de 1874 , arts. $24,25,26,27,28,36,82 \S 2,89 \S 3 ; 99 \S 5,121$ a 124,179 a 185,187 a 189,191 a 193 , etc. 
mental, o direito processual, - eis a materia da actividade forense. No titulo de Direito ou facto juridico (contracto, testamento, acções), nas leis, e na praxe, encontra o agente forense uma substancia em potencia para sobre ella desenvolver a sua actividade.

- No fôro extrajudicial, o facto juridico apparece ou como contracto, ou como testamento ou disposição de ultima vontade, ou como registro e protesto. A materia circa quam, no fôro extrajudicial e no que diz respeito aos factos consiste, portanto, nas diversas especies de contractos, testamentos ou disposições de ultima vontade, registros e protestos. Enumeremos:

1. Doação inter vivos. Dote. Doação causa mortis.

2. Deposito.

3. Mandato. Procuração.

4. Emprestimo: mutuo; commodato.

5. Compra e Venda. Doação em pagamento. Troca ou permuta.

6. Locação: aluguel, arrendamento; locação de serviços.

7. Sociedade.

8. Penhor.

9. Hypotheca.

10. Fiança.

11. Onus reaes:

a) Penhor agricola

b) Servidão.

c) Uso.

d) Habitação.

e) Antichrese.

f) Usofructo.

g) Foro ou aforamento.

h) Legado de prestações ou alimentos expressamente consignados no immovel. 
12. Testamento.

a) Testamento publico aberto;

b) Testamento cerrado; approvação;

c) Testamento privado aberto;

d) Testamento nuncupativo;

e) Testamento dos soldados e pessoas que morrem na guerra.

f) Testamento maritimo.

13. Codicillos

14. Registro Geral:

a) Transcripção de transmissões de immoveis;

b) Transcripção de onus reaes;

c) Inscripção de hypothecas;

d) Averbações;

e) Transcripção de documentos.

15. Registros especiaes:

a). Matricula de commerciantes e de agentes auxiliares do commercio;

b) Inscripção de firmas ou razões commerciaes, averbações;

c) Registro de marcas de fabrica e de commercio e outros de competencia das juntas commerciaes; archivamentos de contractos e distractos das sociedades commerciaes.

d) Registros de testamentos e codicillos; inscripção fiscal dos mesmos.

16. Protesto de letras e titulos semelhantes.

No fôro judicial, o facto apparece como sujeito á apreciação do juiz, ou para remediar uma violação de direito ou para confirmar actos voluntarios. No primeiro caso, ha jurisdicção contenciosa e acção, que é o remedio de direito para pedir ao Juiz que obrigue outrem a dar ou fazer aquillo de que tem obrigação perfeita; no segundo caso ha jurisdicção graciosa, que os praxistas costumam a 
denominar officio nobre do juiz; e homologação, pela qual o juiz declara terem sido cumpridos, em relação ao acto que the é submettido, todas as formalidades e solemnidades legaes.

No fôro judicial criminal, porem, a jurisdicção é sempre contenciosa, dando lugar á acção, que póde ser provocada ou pela parte ou pelo ministerio publico, ou mesmo iniciada pelo juiz ex-officio, nos casos legaes.

Em todo o caso, quer no fôro judicial civil ou commercial, quer no fôro criminal, a acção depende não só dos actos do processo, como egualmente da connexão logica entre o facto, o direito e o pedido. Muito propositalmente deixamos de apreciar as diversas accepções da palavra acção, assim como os principios fundamentaes e distincções scientificas que legitimam essa instituição: taes elocubrações pertencem á theoria do processo, ou como diz Mendes, Pratica Lusitana IV, prefat. n. 1 - parum nobis conducant ad praxim. Nem nos preoccuparemos com os nomes das acções, senão para indicar cautelas relativas á necessidade de ser o pedido uma consequencia do facto e do direito applicavel, e para indicar as cautelas relativas á defeza que assiste aos citados; hoje, depois do decreto do Santo Padre Alexandre III, expedio em 1160 e inserto no L. II, tit. 1, de Judiciis, cap. Dislecti, das Decretaes -, as acções são intentadas sem declaração do nome respectivo, bastando que o pedido decorra logica e juridicamente do facto e do direito applicavel e que sejam praticados todos os actos do curso legal do processo. Ora, taes actos são de duas especies: actos da causa (acta causa) e actos do juizo (acta judicia), os primeiros referem-se á accusação e á defesa, os segundos referem-se á citação e mais actos do expediente processual. Uns e outros actos constituem a materia circa quam do fôro judicial. Passernos a enumerar os actos da causa e depois os actos judiciaes:

I. No fôro civel e commercial:
A. Proposição da acção.
B. Excepção. 
C. Contestação. Reconvenção.

D. Replica.

E. Treplica.

F Assistencia. Autoria. Opposição.

G. Dilação probatoria; provas:

a) Instrumentos publicos e particulares;

b) Confissão.

c) Juramento suppletorio

d) Juramento in litem;

e) Inquirição de testemunhas;

f) Depoimento da parte

g) Arbitramento.

h) Vistoria.

i) Presumpções.

H. Razões finaes.

I. Julgamento:

a) Supprimento ou pronunciamento de nulidades;

b) absolvição ou condemnação.

J. Recursos:

a) Embargos;

b) Aggravos;

c) Appellação.

K. Execução:

a) Liquidação do pedido e custas;

b) Pagamento ou nomeação de bens: á penhora ;

c) Avaliação;

d) Remissão; arrematação; adjudicação;

e) Incidentes: embargos do executado; embargos de terceiro; concurso de credores.

No processo summario, no sumarissimo e no executivo não são realisados todos esses actos: elles são todos suc- 
cessivamente realisados no processo ordinario. $\mathrm{Ha}$, alem disso, actos especiaes proprios de processos tambem especiaes, taes são:

A. Sequestro, arresto, detenção pessoal, exhibição, deposito, venda judicial.

B. Fallencias:

a) Declaração da fallencia ,

b) Arrecadação dos bens do fallido;

c) Reunião de credores; concordata;

d) Contracto de união; liquidação do activo e passivo;

e) Qualificação da fallencia,

f) Rehabilitação do fallido.

C. Moratoria. Cessão de Bens. Liquidação judicial.

D. Immissão e manutenção de posse:

a) Posse em nome do ventre;

b) Nunciação de obra nova e caução de opere demoliendo;

c) Preceitos comminatorios; conversão da notificação em simples citação;

d) Passagem, expedição, divisão de: aguas.

E. Inventario e partilha:

a) Titulo de herdeiros;

b) Descripção e avaliação de bens,

c) Licitação;

d) Collação

e) Partilha.

F Divisão e demarcação de terras particulares:

a) Actos communs: louvação, propositura da acção, contestação, replica e treplica, dilação, razões finaes e julgamento do petitorio. Primeira di- 
ligencia: exame e conferencia dos titulos das partes; verificação do ponto de partida da medição do perimetro, ou reconhecimento do marco primordial, rumos e vestigios; trabalho technico do agrimensor. Resolução de duvidas occurrentes; allegações sobre os trabalhos da divisão ou demarcação.

b) Actos peculiares á divisão: petição e petitorio. Segunda diligencia da divisão: exame, classificação e avaliação das terras; calculo das áreas classificadas ou avaliação do immovel no seu todo; calculo para o orçamento da divisão; partilha geodesica ou operações para separação, medição e demarcação dos quinhões.

c) Actos peculiares a demarcação: petição e petitorio. Segunda diligencia . Percurso dos limites, exame e verificação dos rumos e marcos.

Apontemos, agora, os actos que, na classificação dos praxistas, se denominam acta judicii ou actos judiciaes propriamente ditos:

A. Citação ou chamamento a juizo:

a) Por despacho,

b) Por mandado;

c) Por precatoria ou rogatoria,

d) Por edital,

e) Por carta do escrivão;

f) Citação com hora certa.

B. Notificação:

a) Notificação simples; 
b) Notificação com preceito comminatorio;

c) Notificação com prazo e comminação.

C. Intimação :

a) Intimação de despacho.

b) Intimação de sentença.

D. Pregão:

a) Pregão em audiencia;

b) Pregão nas posses;

c) Pregão em praça.

E. Penhora, sequestro, arresto, deposito. Cauções.

F. Expediente dos feitos:

a) Accusação da citação, da notificação ou da penhora, em audiencia. Contumacia: circunducção, revelia. Conversão da notificação em citação. Instauração, absolvição, perempção, restauração da instancia.

b) Assignação de prazos ou termos processuaes. Lançamento.

c) Autuação, data, juntada, vista, concluão, remessa, recebimento, apresentação, publicação, etc.

d) Actos concurrentes, prejudiciaes ou em proveito de alguma das partes.

Vamos, agora, rememorar os actos processuaes do officio nobre do Juiz:

A. Casamento civil:

a) Exhibição de documentos;

b) Proclamas;

c) Celebração.

B. Emancipação e supplemento de idade.

C. Nomeação de tutores e curadores. 
D. Supprimentos de licença e outorgas.

E. Permuta e subrogação de bens inalienaveis.

F Prestação de contas.

G. Inventario e partilha amigavel.

H. Abertura de testamento e codicillo;

I. Reducção do testamento nuncupativo; reducção do testamento privado aberto; reducção do casamento em articulos mortis.

J. Justificações avulsas, insinuações, habilitações, etc.

K. Protestos e contraprotestos;

L. Compromisso arbitral.

M. Arbitrio de bom varão.

N. Reforma de autos perdidos.

O. Matricula Torrens,

P Diligencias preparatorias; diligencias ad perpetuam rei memoriam, etc.

Q. Correições, etc.

II. Até aqui temos enumerado os autos do fôro civel e commercial. Passemos ao fôro criminal, classificando primeiramente os actos do processo policial - depois do processo criminal propriamente dito:

A. Inquerito policial:

a) Corpo de delicto directo,

b) Exames e buscas para a apprehensão de instrumentos e documentos;

d) Perguntas ao réo e ao offendido;

c) Inquirição de testemunhas;

e) Em geral, tudo o que fôr util para esclarecimentos do facto e suas circunstancias.

B. Summario ou formação da culpa:

a) Queixa, denuncia; procedimento ex officio; recursos contra a não acceitação da queixa ou denuncia, 
b) Suspeição declarada pelo proprio juiz; Incompetencia. Prescripção do crime.

c) Qualificação do réo;

d) Perguntas ao offendido, queixoso ou denunciante;

e) Inquirição de testemunhas. Juntada de documentos e justificações processadas em outro juizo.

f) Pronuncia, não pronuncia. Recursos: sustentação; despronuncia Rol de culpados; baixa na culpa.

C. Plenario:

a) Libello; addição;

b) Contrariedade;

c) Suspeições e recusações;

d) Accusação e defeza perante o jury; replica, treplica. Provas.

e) Julgamento: quesitos, respostas, desclassificação, absolvição, condemnação; determinação da pena:

f) Publicação e intimação da sentença.

I. Concurso de agravantes e attenuantes:

a) No caso de compensação, grau medio

b) Preponderando aggravantes, grau intermedio entre o medio e o maximo,

c) Preponderando attenuantes, grau intermedio entre o medio e o minimo.

d) Ausencia de aggravantes e attenuantes, grau medio.

e) Sendo o crime acompanhado de uma ou mais circunstancias attenuantes, sem nenhuma aggravante, grau minimo.

D. Appellação.

a) Appellação do juiz; voluntaria, exofficio. 
b) Appellação do ministerio publico;

c) Appellação do réo.

E. Execução da sentença e da pena. Incidentes:

a) Desclassificação legal do delicto;

b) Suspensão da pena (art. 68 do Cod.)

c) Minoração legal da pena,

d) Indulto, amnistia, commutação;

e) Prescripção da condemnação;

f) Rehabilitação por sentença de revisão;

g) Livramento condicional.

Estes actos são os do processo ordinario, isto é, dos crimes que devem ser julgados pelo jury; nos processos da competencia policial, da especial e da privativa, esses actos ou se reduzem ou soffrem modificações. E' excusado dizer que, tambem no fôro criminal, alem desses actos da causa, ha tambem os mesmos actos judiciaes do processo civil, salvo algumas modificações e ainda outros actos de ordem especial. Enumeremos os actos que soffrem modificações e os especiaes:

A. Citação ou chamamento a juizo:

a) Por despacho;

b) Por mandado;

c) Por precatoria.

d) Por carta do escrivão.

B. Notificação.

C. Intimação.

D. Prisão:

a) Prisão em flagrante delicto;

b) Prisão sem culpa formada; prisão preventiva;

c) Conducção debaixo de vara;

d) Prisão em cumprimento de sentença. 
E. Livramento

a) Livramento sem prisão nem fiança;

b) Livramento com fiança:

I. Fiança provisoria: tabella.

II. Fiança definitiva; arbitramento.

c) Livramento por não pronuncia ou despronuncia; baixa na culpa,

d) Livramento por prescripção,

e) Livramento por extincção da pena;

f) Livramento condicional;

g) Livramento por habeas-corpus.

Passemos agora aos actos do processo dos recursos:

A. Aggravo de petição, aggravo de instrumento, carta testemunhavel.

a) Interposição;

b) Minuta;

c) Contra minuta

d) Seguimento;

e) Distribuição.

f) Julgamento; sorteio dos adjuntos; Relatorio, discussão, votação do relator e adjuntos; conhecimento; provimento, não provimento.

B. Recursos de pronuncia e não pronuncia e outros:

a) Interposição;

b) Seguimento;

c) Distribuição;

e) Julgamento: relatorio; discussão, votação do relator e adjuntos. provimento, não provimento;

C. Appellação criminal:
a) Interposição;
b) Seguimento;
c) Distribuição; 
d) Razões,

e) Relatorio; passagens.

f) Julgamento: discussão e votação de todos os juizes: annullação do processado; volta a novo jury; absolvição, reforma da pena; confirmação.

D. Protesto por novo julgamento. Interposição.

E. Appellação civel:

a) Interposição;

b) Recebimento;

c) Deserção; seguimento;

d) Distribuiç̧ão;

p) Razões,

f) Relatorio, passagens,

g) Julgamento: discussão, votação do relator e dos dous revisores: conhecimento, confirmação, reforma.

h) Embargos, impugnação; sustentação. Julgamento: discussão e votação dos juizes certos; confirmação, reforma.

F Recurso de revisão.

Ha causas que os tribunaes superiores conhecem em primeira e unica instancia, taes são: o habeas corpus, os crimes communs ou de responsabilidade de competencia desses tribunaes, os conflictos de jurisdicção, a prorogação do tempo de inventario, as suspeições e habilitações incidentes. Nesses processos, tanto os acta causae como os acta judicii são cumpridos com as modificações apropriadas.

Quanto ao direito objectivo, temos a verificar o direito positivo, sob os seguintes aspectos:

A. Direito patrio:

a) Leis sobre o direito civil, commercial e criminal (Const. Fed. arts. $34 \mathrm{n}$. 23) 
1) Ordenações Phillipinas (Art. 83 da Const. Fed., Lei de 20 de Outubro de 1823).

2) Codigo Commercial.

3) Codigo Penal (Dec. n. 847 de 11 de Outubro de 1890)

4) Principaes leis avulsas, posteriores ás Ordenações e aos Codigos (Dec. n. 181 de 24 de Janeiro de 1890 (casamento civil) Lei de 31 de Outubro de 1831 (emancipação aos 21 annos) Dec. n. 169 A de 19 de Janeiro de 1890 e n. 370 de 2 de Maio de 18 (o (Hypotheca) Dec. n. 917 de 24 de Outubro de 1890 (fallencias)

b) Leis processuaes:

1) Organisação judiciaria e processual da justiça federal (dec. n. 848 de 11 de Abril de 1891)

2) Organisação judiciaria e processual no Districto Federal (dec. n. 1030 de 14 de Novembro de 1890)

3) Na maioria dos Estados.

Deci. n. 763 de 17 de Setembro de 1890 ; Reg. n. 737 de 25 de Novembro de 1850; Codigo de Processo Criminal Lei de 3 de Dezembro de 184.1, Reg. n. 120 de 31 de Janeiro de 1842, Reg. de 15 de Março de 1842 , Lei n. 2033 de 20 de Setembro de 1871 e Dec. n. 4824 de 22 de Novembro de 1871; Dec. n. 5467 de 12 de Novembro de 1873, Dec. n. 5618 de 2 de Maio de 1874 , 
Decr. n. 948228 de Abril de 1885; Dec. n. 9549 de 23 de Janeiro de 1886; Dec. n. 370 de 2 de Maio de 1890 , etc. etc.

B. Praxe:

a) Usos, estylos, costumes;

b) Arestos dos tribunaes;

c) Assentos

d) Principaes praxistas portuguezes e brasileiros.

- Apontemos as cautelas de que devemos cercar a causa material, para que ella tenha a potencialidade de revestir uma forma forense regular e valida:

A. Contracto. Cautelas relativas:

a) Objecto contractual: qualidade, alienabilidade, inexistencia de onus, quantidade e caracteristicos.

b) Modo contractual: condições, prazos, encargos.

B. Testamento e codicillo. Cautelas relativas.

a) Objectos testamentarios:

1) Instituição de herdeiros;

2) Desherdações;

3) Substituições;

4) Legados puros e simples, legados de usofructo, etc.

5) Fideicomisso;

6) Reconhecimento de filhos naturaes;

7) Nomeação de tutores e curadores;

8) Desencargos de consciencia ;

9) De sepultis e bem dalma;

10) Nomeação de testamenteiros. 
b) Modos testamenteiros, condições, prazos, encargos, demonstrações, causas.

C. Acções pessoaes, acções reaes, acções pessoaes in rem scriptae, acções mixtas. Acções penaes publicas e acções penaes privadas. Cautelas relativas:

a) Exame do facto violador do direito e de suas circunstancias;

b) Estudo das leis applicaveis ao facto e suas circunstancias;

c) Segurança das provas do facto e de suas circunstancias.

d) Positividade, certeza, congruencia do pedido:

1) Verificação da acção competente para o caso;

2) Verificação de quantas acções podem ser intentadas para o mesmo fim;

3) Si mais de uma, cumulal-as sendo compativeis, escolhendo a mais commoda sendo incompativel;

5) Verificação de quando a acção se pode intentar contra uma só pessoa e quando é forçoso intentar contra pessoas diversas. Pedido simples, pedido alternativo, pedido cumulado. Pedido liquido, pedido illiquido-Pedidos nas acções penaes;

6) Verificação si a acção está ou não prescripta.

e) Meios de defeza indirecta e causa de defeza directa.

D. Actos processuaes (Vide pg. 65) 
E. Direito (Vide pg. 67) Cautelas relativas

a) Consulta das leis, busca dos textos, manejo das leis compiladas, das leis consolidadas e dos codigos, decretos, regulamentos, instrucções, regimentos, avisos, ordens e circulares;

b) Obrigatoriedade das leis e dos actos do poder executivo da União e dos Estados (Dlecr. n. 572 de 12 de Julho de 1890)

F Praxe (Vide pag. 69).

\section{CAPITULO IV}

SUMMARIO - Causa formal da actividade forense-Formalidades menos solemnes-Instrumentos publicos, instrumentos particulares; instrumentos originaes, instrumentos copiados; instrumentos extrajudiciaes; instrumentos extrajudiciaes; instrumentos judiciaes. Caultelas e formulas.

A causa formal da actividade forense é, como já tivemos occasião de explicar, restricta a forma litteral, que reproduz e guarda a palavra; e por ser destinada a instruir o processo e o juiz, veio essa fórma tomar, na technica, a denominação de forma instrumental ou instrumentos.

A forma instrumental consiste, pois, na palavra fallada e na palavra escripta; no estado actual da jurisprudencia pratica, somente da palavra se servem aquelles que efficazmente querem representar os actos juridicos.

Mas, a palavra, além de subordinada ás regras da grammatica e da calligraphia, tem ainda de adaptar-se ás 
exigencias peculiares da vida forense, onde as designações technicas e o estylo especial muito contribuem para a facilidade do movimento.

A nossa lingua começou a ser empregada em documentos forenses nos reinados de D. Affonso III e de D. Diniz, isto é, do seculo XIV em diante; além disso, todos os contractos e mesmo os processos, que se conhecem, eram escriptos em latim e alguns em um latim barbaro e corrupto. A linguagem portugueza dos documentos do seculo XIV é uma versão litteral do antigo formulario latino. Não nos compete aqui entrar em indagações relativas á progressiva marcha da ortographia e da calligraphia: quem quizer esclarecer-se a esse respeito, recorra aos tratados de paleologia e poleographia. Até o principio do seculo dezenove, ainda se sentiam no fôro alguns restos do uso do latim; pois o ultimo golpe foi dado pelo Dec. de 23 de Maio de 1821, que assim dispoz: "Fica abolido o estylo das tenções em latim, praticado nas Relações do Reino; devendo aquellas ser escriptas em lingua portugueza."

O dictado, a leitura, o pregão, o discurso-constituem, em regra, o modo de emissão da palavra fallada no fôro; a letra cursiva, ortographica e calligraphicamente regulacia, é empregada para a escripta. As disposições legaes recommendavam sempre, na escripta, a maxima clareza, e nesse pensamento a Lei de 19 de Junho de $1776 \S 6$, reprovou toda a letra de caracteres encadeados, afim de serern bem separadas as palavras.

Devemos portanto, estudar a palavra sob os seguintes pontos de vista:

A. Dictado, leitura. Pregão. Discurso.

B. Escripta .

a) Letras alphabeticas, algarismos; signaes,

b) Escripta por extenso; abreviat:Iras; divisão do texto;

c) Ortographia; calligraphia, rasa . 
d) Erro, inhabilidade, descuido na escripta. Emenda, entrelinha, risco, cancellamento, rasura, resalva, accrescimo e o mais que duvida faça;

e) Verdade, authenticidade:

C. Data:

a) Lugar: cidade, villa, freguezia, districto; casa publica; casa particular;

b) Tempo: anno, mez e dia.

D. Identidade pessoal. Nomes:

a) Nome patronymico;

b) Nome titular;

d) Nome do cargo ou do officio;

d) Idade, estado, profissão, residencia,

e) Tratamentos dos juizes, autoridades e officiaes publicos;

f) Assignatura pelo proprio punho, assignatura a rogo. Subscripção. $\mathrm{Ru}$ brica. Signal publico, signal raso.

E. Declaração da vontade. Exposição do facto, do direito e do pedido.

Cautelas importantes devemos ter em relação ao papel, á tinta e mais material onde se forma a palavra escripta. Temos pois de considerar:

A. Dimensões e disposição do papel:

a) Folhas;

b) Linhas ou regras;

c) Margens:

d) Rasa

e) Sello

B. Folhas avulsas, folhas autoadas, folhas appensadas, folhas encadernadas, folhas impressas com os claros precisos, permittidos pela lei e pela praxe. 
C. Autos pendentes, autos appensados, autos findos.

a) Autuação e numeração de folhas;

b) Juntada

c) Appenso por linha.

d) Archivamento. Buscas.

D. Protocollos. Livros de notas. Livros de Registros. Livros auxiliares.

a) Abertura, numeração e rubrica de folhas, encerramento;

b) Dimensões e disposição de cada folha,

c) Sello e exigencias fiscaes.

I. Protocollos:

1) Protocollo de distribuição (Ord. L. I, tits. 84 e 85: Dec. Fed. de 8 de Agosto de 1891 (regimento interno do Supremo Tribunal Federal, arts. 32 e 35 e art. 141 n. 6) ; regimentos dos tribunaes estadoaes, etc.)

2) Protocollo de audiencias (Ord. L. III, tit. 19, princ.: reg. de 7 de junho de 1605, art. 12; Alvará de 4 de Junho de 1823; Dec. n. 9420 de 28 de Abril de 1885, art. 339)

3) Protocollo do Registro Geral (Dec. n. 370 de 2 de Maio de 1890, arts. 10, 11 n. 1 e 23: Dec. n. 544 de 5 de Julho de 1890, modelo n. 1)

4) Protocollo de protesto de letras e titulos (Cod. Comm. art. 408; Reg. n. 737 de 25 de Novembro de 1850 , art. 380)

5) Protocollo do Registro Publico do Commercio (Dec. n. 596 de 19 de Julho de 1890 , art. $48 \S 2$ n. 6) 
6) Protocollo do Registro especial de documentos (Decr. n. 4755 de 16 de Fevereiro de 1903, art. 11)

II. Livros de notas (Ord. L. I. tit. $78 \$ 4$, tit. 80, princ. Decr. n. 9420 de 28 de Abril de 1885 , arts. 26 e 29 ).

III. Livros de Registro:

1) Livro de Registro Civil (modelos do Decr. n. 9886 de 7 de Março de 1888),

2) Livros do registro de documentos (Decr. n. 5738 de 2 de Setembro de 1874, art. 1; Decr. n. 9420 de 20 de Abril de 1885, arts. 26 e 27; Lei n. 973 de 2 de Janeiro de 1903 ; Decr. n. 4775 de 2 de Fevereiro de 1903, art. 11),

3) Livros do Registro Geral de transmissões de immoveis, hypothecas e onus reaes (Decr. n. 370 de 2 de Maio de 1890, arts. 11 a 39; modelos do Decr. n. 544 de 5 de Junho. de 1990)

4) Livro do Registro das associações moraes, scientificas, artisticas ou de simples recreio (Decr. n. 173 de 10 de Setembro de 1893)

5) Livros do Registro do Ponto e protesto de letras (Lei de 15 de Novembro de 1827, Cod. Comm. arts. 408 a 411 , Reg. n. 737 de 25 de Novembro cie 1850 , arts. 381 e segs)

6) Livro de Registro de testamentos (ord. L. I, tit. 63; Alvará de 2 de Dezembro de 1604, Regimento de 7 de Janeiro de 1692), 
7) Livros do Registro Publico de Commercio (Dec. n. 596 de 19 de Julho de 1890 , art. $48 \$ 2$ e art. 67; Dec. n. 916 de 24 de Outubro de 1890),

8) Livros de Registro de Contas:

9) Livros de arrecadação, administração, entradas e sahidas de bens de orphãos (Alvará de 21 de Julho de 1559)

10) Livros para contabilidade dos bens de defunctos e ausentes e vagos (Decr. n. 243 de 15 de Junho de 1859 , arts. 13 e segs.)

11) Livro de arrecadação do residuo (Decr. n. 884 de 2 de Outubro de 1851 , art. $35 \$ 3)$,

12) Livro do tombo ou registros dos bens e rendimentos das pessoas juridicas sujeitas a provedoria (Decr. cit. art. $27 \$ 7,44 \$ 7$ e 463$)$

13) Livro de custas, etc.

14) Livro dos registros dos Tribunaes e auditorios (Regimento do Supremo Tribunal Federal, de 8 de Agosto de 1899, art. 141; Decr. n. 5618 de 2 de Maio de 1873, etc.)

IV Livros policiaes e criminaes:

1) Livros de registro de entrada e sahida de presos (Reg. n. 120 de 31 de Janeiro de 1842, art. 158)

2) Livro de rol dos culpados (Ord. L. V, tit. $125 \$ 6$; Reg. n. 120 de 31 de Janeiro de 1842, art. 293) 
V Livros auxiliares, determinados por lei:

1) Livros auxiliares do Registro Geral (Dec. n. 544 de 5 de Julho de 1890, modelos)

2) Livros de cargas e descargas para vistas, remessas, vista e conclusões (Assento de 11 de Agosto de 1767: Dec. n. 4824 de 22 de Novembro de 1871 , art. 72 in fine)

VI. Livros introduzidos pela praxe:

1) Indices, memoranduns, etc.

- A forma litteral, quando confeccionada para exemplificar ou modelar os actos forenses, denomina-se formula forense.

Os requisitos da formula denominam-se formalidades externas. Estas, dividem-se em solemnes e não solemnes: as primeiras são determinadas mais por motivo de ordem publica do que por necessidade de exprimir a intenção dos agentes, e denominam-se solemnidades; as segundas são destinadas principalmente a exprimir a intenção dos agentes e tomam, conforme a natureza do acto, diversas denominações, taes como clausulas, artigos, quesitos, perguntas, respostas, considerandos, etc.

As solemnidades são substanciaes, essenciaes ou intermediarias ou accidentaes: aquellas que a lei prescreve, sob pena de nullidade do acto e do instrumento, são substanciaes; essenciaes ou instrumentarias aquellas que a lei prescreve sob pena de nullidade simplesmente do instrumento; accidentaes-aquellas que podem ser omittidas sem nullidade quer do acto, quer do instrumento. Entre as solemnidades, ha algumas que consistem em phrases consagradas por praxe inveterada e que tomam a denominação de - formalidades tabelliôas; é cautela utilissima não alteral-as por 
anteposição ou proposição, nem substituil-as por equipollencia de palavras. Aliás, na nossa legislação, ha formulas com solemnidades rigorosamente determinadas: - são, por exemplo, as do arts. 27 e 28 do Decr. n. 181 de 24 de Janeiro de 1890 , relativas ao contracto matrimonial, e, em relação aos testamentos, o bom tabellião, apezar das interpretações que têm sido dadas ao Assento de 10 de Junho de 1817, deve, nos termos do Assento de 17 de Agosto de 1811, formalizar os testamentos publicos e os instrumentos de approvação dos testamentos cerrados, com as palavras da Ordenação L. IV, tit. 80. Não é razoavel exigir a supersticiosa observancia e a tenaz adhesão as palavras; isso porem, não autorisa o relaxamento das solemnidades legaes, o abandono de formulas consagradas por praxe inveterada, esse thesouro da experiencia, formulas que, na phrase de Bacon "mostram os mysterios das leis á semelhança da mão fechada e da mão aberta", ad instar pugni et palmae.

As clausulas, os artigos, os quesitos, as perguntas, as respostas, os considerandos, e outras formalidades não solemnes-consistem em phrases que os respectivos agentes livremente escolhem e empregam para melhor exprimir a sua intenção, de accordo com as variadas circunstancias dos factos e com as differentes disposições de direito. Nestas ordens de formalidades, ha algumas que, por serem connexas com a intenção declarada, reputam-se escriptas ainda que tenham sido omittidas: no fôro extrajudicial, taes formalidades denominam-se-clausulas consuetudinarias ou subentendidas; no fôro judicial, quando o direito é evidente, é desnecessario allegal-o. Em todos os outros casos as formalidades devem ser expressamente consignadas, ainda que, á primeira vista, pareça ser possivel subentendel-as: essas, no fôro extrajudicial, denominam-se claulsulas insolitas; e, no fôro judicial, a regra é que os factos, o direito não evidente, o pedido das partes, os quesitos, as perguntas, as respostas das testemunhas e auxiliares do juizo, assim como os fundamentos das decisões dos juizesdevem ser sempre expressamente consignados. 
- A forma instrumental, expressão por escripto dos actos juridicos, póde ser classificada ou sob o ponto de vista da causa efficiente, ou sob o ponto de vista da derivação, ou sob o ponto de vista do fôro.

Sob o ponto de vista da causa efficiente dividem-se os instrumentos em publicos e particulares; sob o ponto de vista da derivação, dividem-se em originaes e extrahidos; sob o ponto de vista do fôro, dividem-se em instrumentos. extrajudiciaes e instrumentos judiciaes. Cada uma dessas especies tem importantes subdivisões.

I. Instrumento publico, é o lavrado por funccionarios de fé publica e revestidos de solemnidades legaes. Instrumento particular é o escripto por particulares ou por funccionarios sem fé publica.

II. Instrumento original é aquelle que primitivamente foi lavrado ou escripto sobre o facto juridico, assim como aquelle cujo conteudo por extenso ou por extracto, foi lançado em algum livro de registro. Instrumento extrahido e o que se refere ao original, ou por ser delle copiado palavra por palavra, ou por ser uma narração ou descripção resumida do seu conteudo, nesse sentido, o instrumento extrahido, subdivide-se nas seguintes especies: traslados, extractos, publica-forma, certidão verbo ad verbum, cerłidão em relatorio, simples copia, traducções.

III. Instrumentos exirajudiciaes são os lavrados por quaesquer officiaes pubiicos e os instrumentos particulares emquanto não produzidos em juizo; instrumentos judiciaes são os termos, autos, fés ou certidões de actos processuaes, despachos, mandados, alvarás, sentenças, etc, assim como quaesquer instrumentos publicos ou particulares, logo que sejam produzidos em juizo.

A potencialidade da causa material e a actualidade da causa final ligam-se intimamente á efficacia da causa efciente. Actos ha para os quaes basta o impulso de um 
só agente; outros, porem, dependem do concurso de diversos agentes. Convem, pois, attender as seguintes cautelas:

A. No fôro extrajudicial:

a) Actos que podem ser lavrados por escrevente juramentado (ou habilitado por compromisso) e que devem ser conferidos e subscriptos por tabellião, dictados e assignados pelas partes ou seus legitimos representantes ou assistentes, presenciados e assignados por duas testemunhas pelo menos.

b) Actos que devem ser escriptos e subscriptos pelo proprio tabellião, dictados e assignados pelas partes ou seus legitimos representantes ou assistentes, presenciados e assignados por duas testemunhas pelo menos.

c) Actos que devem ser escriptos e subscriptos pelo proprio tabellião, dictados e assignados pelas partes, assistidos e assignados, em um acto e contexto, por cinco testemunhas varões e puberes; - actos que devem ser escriptos pelo proprio tabellião com as mesmas formalidades dos antecedentes, porem assistidos e assignados por quatro e até por trez testemunhas pelo menos.

d) Actos que podem ser escriptos e subscriptos por tabellião ou escriptos por escreventes e conferidos e subscriptos por tabellião.

$e)$ Actos que devem ser escriptos e subscriptos por official de registro; actos que podem ser escriptos por sub-offi- 
ciaes e ajudantes e subscriptos pelo official.

f) Actos que devem ser escriptos e assignados pela propria parte; actos que devem ser escriptos e assignados pela propria parte e tambem assignados por duas testemunhas pelo menos; actos que podem ser impressos ou escriptos por outrem e assignados pela parte; actos que podem ser escriptos por outrem e assignados por qualquer pessoa a rogo da parte, por esta não saber ou não poder escrever.

g) Actos que escriptos pela propria parte, não é necessario que sejam por ellas assignados; actos que podem ser escriptos por outrem e que devem ser assignados pela pessoa que os escreveu, a rogo da parte, por esta não saber ou não poder escrever: actos que escriptos por outrem, devem ser assistidos e assignados por seis testemunhas, inclusive essa pessoa que os escreveu; actos que devem ser assignados por uma das testemunhas numerarias, a rogo da parte, por esta não saber ou não poder escrever.

B. No fôro judicial:

a) Actos que somente pela propria parte devem ser praticados, actos que podem ser praticados pelas partes ou seus procuradores, actos que podem ser feitos sómente por advogado; actos que pódem ser feitos por 
advogado ou solicitador; actos que devem ser dictados por advogados, solicitadores, defensores, excusadores e escripios pelo escrivão.

b) Actos que devem ser feitos pelos orgãos do Ministerio Publico.

c) Actos que devem ser feitos sómente pelo Juiz; actos dictados pelo Juiz e escriptos pelo escrivão; actos que devem ser escriptos e subscriptos pelo escrivão na presença do juiz e por este assignados; actos que podem ser escriptos e subscriptos pelo escrivão, para serem depois submettidos á assignatura ou rubrica do Juiz; actos escriptos e subscriptos pelo escrivão e que devem ser assignados pelo Juiz e pelas partes; actos escriptos e subscriptos pelo escrivão e que devem ser assignados pelo Juiz, avaliadores, arbitradores, peritos ou expertos; actos escriptos e subscriptos pelo escrivão e que devem ser assignados pelo Juiz e partidores; actos escriptos e subscriptos pelo escrivão e que devem ser assignados pelo Juiz, testemunhas e partes presentes.

d) Actos que são feitos pelo escrivão somente; actos que podem ser escriptos por escrevente ou ajudante e que devem ser subscriptos pelo escrivão; actos escriptos pelo escrivão e que devem ser assignados pelas partes e por duas testemunhas.

e) Actos escriptos e subscriptos pelc distribuidor; actos escriptos e subs- 
criptos pelo contador; actos feitos pelo escrivão e assignados pelos partidores; actos escriptos por um dos arbitradores, avaliadores, peritos ou expertos e por todos assignados.

f) Actos que devem ser feitos por um só official de Justiça; actos que devem ser feitos por dous officiaes de Justiça; actos do porteiro dos auditorios.

\section{Instrumentos extrajudiciaes}

Toda a escriptura publica de contractos e actos entre vivos, deve conter quatro partes: introducção, policitação, acceitação e estipulação; e, se houver intervenção de terceiros, haverá essa quinta parte entre a acceitação e estipulação.

\section{A. Introducção}

a) Determinação do contracto, dos contractantes e de valor. - Ex. Escriptura publica de compra e venda que fazem $F$ e $F$ no valor de....\$........

b) Formula preambular. Saibam quantos este publico instrumento virem que...

c) Anno, mez e dia (Od. L. I, tit. 80 $\$ 7)$ : ex... no anno do Nascimento de Nosso Senhor Jesus Christo de mil novecentos e.....

d) Cidade, villa, freguezia, districto, casa particular, casa publica (Ord. L. I, tit. 80, \$7) : ex... nesta cidade de São Paulo em meu cartorio (ou em casa de $F$ onde a seu chamado fui vindo), 
e) Presença, nomes e mais requisitos determinantes da identidade e capacidade das partes ou de seus representantes ou assistentes legaes (Ord. L. I, tit. $78 \$ 6)$ : Ex. 1. ${ }^{a}$ Hypothese)... ahi perante mim compareceram, partes justas e contractadas, como outorgante vendedor (ou locador, ou credor, ou doador, etc.) F... (nome patronymico, estado, residencia) e como outorgado comprador (ou locatario, ou devedor, ou donatario, etc.) F... (nome patronymico, estado, residencia), ambos de mim conhecidos e das tesîemunhas abaixo nomeadas e assignadas, pelas proprias de que trato e dou fé... $2{ }^{2}$ hyp.) :... ahi perante mim compareceram etc... pessoas conhecidas das testemunhas, abaixo nomeadas e assignadas, e estas de mim tabellião, de que dou fé... 3. ${ }^{a}$ hyp.) ahi, perante mim compareceram, etc.... sendo conhecido de mim tabellião somente o contrahente F..., mas todos conhecidos das duas testemunhas abaixo nomeadas, e assignadas, e estas de mim tabellião de que dou fé... $4 .{ }^{a}$ hyp.)... ahi, perante mim compareceram, etc. pessoas não conhecidas de mim tabellião, nem das duas testemunhas do contracto abaixo nomeadas e assignadas, mas conhecidas das testemunhas F. e F., que todos assignam esta e que são de 
mim conhecidas, do que dou fé... 5. ${ }^{a}$ hyp.)... ahi, perante mim compareceram FF (nome patronymico e residencia), na qualidade de procurador do outorgante vendedor (ou locador, credor, etc.) F. (nome patronymico, estado e residencia), cuja procuração me entregou e vae nesta incorporada, e como outorgado comprador ou locatario, ou devedor, etc.) F... N. B. Mutatis mutandis, quando o outorgado, ou ambas as partes, comparecerem, não pessoalmente, mas por procurador. - 6 . $^{\mathrm{a}}$ hyp.) ahi perante mim comparece. ram...F. na qualidade de tutor (ou curador) do impubere F., com o Alvará de autorisação que vae nesta incorporado, etc. e F... $7^{\text {a }}$ hyp.) ahi perante mim compareceram $F$... F., na qualidade de socio da firma $F$ \& Cia. (a razão social) e F... 8. ${ }^{a}$ hyp.) ahi perante mim compareceram... F, menor pubere, assistido de seu tutor $F$ e F...

B. Policitação.

a) Determinação do objecto do contracto; verificação da alienabilidade: situação, confrontações, caracteristicos, quantidade, medida da cousa immovel, declaração de onus se existirem, assim como do modo e titulos anteriores de acquisição; quantidade, medida, qualidade, signaes da cousa movel, ou semovente; qualidade e quantidade dos factos. 
b) Clausula pura e simples; clausula de condição, clausula de prazo; clausula de encargo; clausula penal ex. 1 . $^{\mathrm{a}}$ Hyp.) ...e pelo dito outorgante devedor me foi dito, perante as duas testemunhas abaixo nomeadas e assignadas que, tendo recebido por emprestimo do outorgado credor a quantia de dez contos de reis, obriga-se a pagar na forma da lei logo que the seja exigida... 2. ${ }^{\mathrm{a}}$ hypothese) ... e pelo dito outorgante vendedor... me foi dito etc... que é senhor e possuidor de um predio, sito nesta cidade de S. Paulo, freguezia da Sé, Distr. do Sul, rua..., confrontando pela direita com o predio de F..., pela esquerda com o predio dos herdeiros de $F$... e pelos fundos com o predio de F..., sendo que o terreno do predio aqui descripto mede 10 metros de frente e 120 da frente ao fundo; e por esta vende dito predio ao outorgado $F$ pelo preço e quantia de ..........., que neste acto recebe em moeda corrente, e á pessoa do comprador transmitte toda a posse, jus, dominio e servidões activas que elle vendedor tinha no dito predio... 3. ${ }^{\text {* }}$ hyp.) Outrosim obriga-se a rebaixar a custa delle vendedor o nivel da calçada de frente do predio vendido, caso a Camara Municipal o permitta... 4. ${ }^{\text {}}$ hyp.) ...disse mais o vendedor que se obriga a rebaixar á sua custa o nivel da calçada da frente do predio vendido, logc que, em cum- 
primento da deliberação da Camara Municipal, o respectivo engenheirc determinar a medida do rebaixamento, e isto fará dentro de trinta dias... 5. ${ }^{a}$ hypothese) ... ficando porem o comprador obrigado a permittir que, desta data a um anno, fique habitando o predio vendido como inquilino, pagando o aluguel de .....\$.... mensaes.

C. Acceitação:

a) Acceitação do outorgado presente: ex... pelo outorgado foi dito que acceita esta escriptura tal como nella se contem...

b) Acceitação pelo ausente: ex... e eu tabellião, como pessoa publica, acceitei esta escriptura a bem de quem de direito fôr...

D. Estipulação:

a) Confirmação do accordo das partes e declaração do pedido de instrumento ex... e por se acharem assim justas e contractadas me pediram lavrasse este instrumento....

b) Incorporação do bilhete de distribuição, da siza e mais conhecimentos fiscaes, dos alvarás, das procurações e outros documentos: Ex... e me apresentaram o bilhete de distribuição, datado de hoje, firmado pelo $1 .^{\circ}$ distribuidor, e bem assim o conhecimento ou recibo do pagamento do imposto de transmissão de propriedade pago na Recebedoria de Rendas do Estado (Transcrever o 
documento) alem da procuração lavrada em notas do tabellião $\mathrm{F}$ ou instrumento particular que fica archivado neste cartorio (se houver procurador)...

c) Presença e nome das testemunhas: ex... e perante as testemunhas $\mathrm{F}$ e $\mathrm{F}$. a tudo presentes....

d) Leitura perante as parte e testemunhas, resalva de emendas, entrelinhas, riscos, rasuras, cancellamentos e do mais que duvida faça; declaração de conformidade: ex... e das partes coniractantes li em voz alta o que nella se contem, declarando estas que reciprocamente outorgaram, achando conforme. Declaro em tempo que vale a emenda retro, na linha tal (ou, em tempo, resalvo tal palavra, ou vale tal rasura, ou cancellei tal palavra, etc.)

e) Subscripção do escrivão: eu F., escrevente juramentado, a escrevi, e eu $F$ tabellião, a subscrevi.

f) Assignatura das partes (ou de pessoas a seu rogo, si não puderem ou não souberem escrever) a assignatura das duas testemunhas reconhecidas.

Nas escripturas que contêm obrigações reciprocas, como por exemplo no contracto de sociedade, a policitação e a acceitação fórmam uma só parte. E nas escripturas em que houver intervenção de terceiros, é recessario acautelar:

a) presença, nomes e mais requisitos cia identidade pessoal desse terceiro; 
b) Determinação da causa da intervenção;

c) Declaração de acquiescencia: ex... e neste acto compareceu, perante mim e das testemunhas abaixo nomeadas e assignadas $F$., de mim conhecido (ou das testemunhas) de que dou fé, e por elle me foi dito que, por sua qualidade de fiador (ou credor hypothecario, ou tutor do pubere, etc.) concorda com a presente escriptura...

Em resumo, as solemnidades legaes das escripturas publicas, nos actos inter-vivos são em geral a seguintes (1):

a) Anno, mez e dia (Ord. L. I, tit. 80 (7)

b) Cidade, villa, logar e casa (Ord. cit.)

c) Presença, nomes e reconhecimento de identidade das partes ou de seus legitimos representantes ou assistentes legaes;

d) Presença ou assistencia, nomes e reconhecimento de identidade de duas testemunhas pelo menos;

e) Resalva de emendas, entrelinhas, riscos e rasuras e de mais que duvida faça,

f) Leitura perante as partes e testemunhas

g) Subscripção e fé do tabellião;

h) Assignaturas das partes (ou pessôas a seu rogo, nos casos da lei) e assignatura das duas testemunhas reconhecidas.

(1) A escriptura publica é da substancia dos contractos: 1) Na creação de fundações por actos inter vivos (Cod. Civil Bras. art. 24) ; 2) Na constituirão do bem de familia (Cod. Civil Bras. art. 73); 3) Nos contractos celebrados 


\section{$-95-$ \\ Procurações por escriptura publica}

As escripturas publicas de procuração compõem-se somente de tres partes: introducção, determinação de poderes e estipulação; ahi devem ser observadas as seguintes cautelas.

A. Introducção:

a) Formula preambular;

b) Anno, mez e dia (Ord. L. I, tit. 80 $\$ 7)$,

d) Presença, nomes e mais requisitos determinantes da identidade do outorgante.

e) Presença e reconhecimento de duas testemunhas;

f) Nome do outorgado;

B. Determinação de poderes:

a) Poderes geraes (Cod. Civ. Bras. Art. 1294)

b) Poderes especiaes para o caso (Cod. Civ. art. 1294)

c) Poderes que devem ser sempre especiaes (Cod. Civ. art. $1295 \$ 1$ )

d) Poderes que costumam ser impressos.

C. Estipulação:

a) Confirmação do mandato;

com a clausula de não valerem sem instrumento publico (Cod. Civil Bras. art. 133) 4) Nos pactos ante nupciaes (Cod. Civ. Bras. art. 134 n. I) ; 5). Nos contractos constitutivos ou translativos de direitos reaes sobre immoveis de valor superior a um conto de reis, exceptuado o penhor agricola (Cod. Civ. Bras. art. 134. II) ; 6) Nas adopções (Cod. Civ. Bras. art. 134. n. I) ; 7) Na autorisação dos paes e dos maridos aos filhos menores e ás mulheres casadas, maiores de dezoito annos, para que possam commerciar (Cod. Com. Bras. art. l, ns. 3 e 4); Na compra e venda de embarcações brasileiras destinadas a navegação em alto mar (C. Com. Bras. art. 468 e Reg. n. 11.505 de 4 de Março de 1915, art. 359). 
b) Nomes das testemunhas;

c) Leitura perante o outorgante e testemunhas; resalvas;

d) Subscripção do escrivão;

e) Assignatura do outorgante ou de outrem a seu rogo (si não souber ou não puder escrever) e assignatura das duas testemunhas instrumentarias.

A lei (Decr. n. 2260 de 31-12-97, art. 15, Aviso do Ministro da Justiça, de 2 de Abril de 1875) permitte que os tabelliães tenham um livro especial de procurações impressas con os claros precisos.

Escripturas puólicas de testanenios.

As escripturas publicas de restamentos e disposições causa mortis devem conter quatro partes: Introducção, qualificação pessoal, disposição e encerramento.

A. Introduç̧ão:

a) Determinação da especie do acto causa mortis (testamento, codicillo, ou doação) e da pessoa que dispõe: ex. Escriptura de testamento que faz F (ou de codicillo, ou doação causa mortis...

b) Formula preambular: Saibam quantos este publico instrumento virem que...

c) Anno, mez e dia: ex... que no anno do Nascimento de Nosso Senhor Jesus Christo de mil e novecentos e... aos... dias do mez de... do dito anno; 
d) Estado, cidade ou villa, districto, cartorio ou casa: ex... nesta cidade de S. Paulo, em meu cartorio (ou em casa de $F$ onde a seu chamado fui vindo...),

e) Presença, nome, identidade e capacidade do iestador: ex... e sendo ahi presente o dito $F$., pessoa de mim conhecida de que dou fé, e achando-se doente, mas em seu perfeito juizo (ou achando-se em seu perfeito juizo)...

f) Presença e assistencia, em um acto e contexto de cinco testemunhas idoneas com os seus nomes e reconhecimento de identidade (Cod. Civ. art. 1632, I a IV e 1650) : ex e tambem presentes as testemunhas, em numero de cinco, abaixo nomeadas e assignadas, pelo testador $F$ foi dito, diante de todos, que por sua livre e expontanea vontade faz o seu testamento do modo seguinte...

B. Declarações pessoaes:

a) Verba relativa á religião · ex... que é catholico, apostolico, romano...

b) Verba relativa á filiação, naturalidade, nacionalidade, idade, estado, profissão: ex. que nasceu em... de... filho legitimo de $F$ e $F$., já fallecidos, que é casado com F., exercendo tal profissão, etc.

C. Disposição:

a) Verba da instituição de herdeiro: ex... que institue por seus herdeiros $F$ e $F$ 
b) Verba de desherdação.... ex. que tem justa causa para desherdar seu filho $F$ (declarar uma das causas da desherdação nos termos do Cod. Civil art. 1744 e 1595), por isso institue em seu lugar os outros filhos (ou F.) que provarão em juizo a verdade da mencionada causa (Cod. Civil, art. 1743) ...

c) verba de substituição: ex... que institue $\mathrm{F}$ por seu herdeiro, e se não fôr seu herdeiro seja seu herdeiro $F$., ou que institue por seus herdeiros $F$ e $F$ os quaes substitue entre si... (Cod. Civ. art. 1729 e segs.)

d) Verba de fideicomisso universal: ex. que institue seu herdeiro a F., mas acceitando elle a herança a restituirá a $F$ a que institue herdeiro fideicommissario delle testador...

e) Verba de legados, verba de usofructo, verba de fideicommisso particular' ex. que deixa a metade de seus bens a $F$... que deixa a sua casa da Rua A. em usofructo a F., emquanto viver (ou até tal data) e, em propriedade a $F$., entrando este na posse findo o tempo do usofructo... que deixa seu relogio a $F$., que o acceitando o restituirá a $\mathrm{F}$

f) Verba de reconhecimento de filhos naturaes: ex... que solemnemente reconhece $F$. como seu filho, o qual teve de mulher desimpedida para 
casar, e dito seu filho conta hoje ... annos de idade, morando em tallogar....

b) Verba de desencargo de consciencia: ex... que por negligencia deixou de restituir uma declaração de divida de F a elle testador, mas esta divida já está paga, elle testador recebeu do proprio $F$., e por isso não vale tal declaração de divida, devendo ser restituida a $\mathrm{F}$

h) Verba de sepultis e bem dalma . ex. que quer ser sepultado em tal cidade e que por sua alma devem ser resadas tantas missas, para o que deixa tal quantia.

i) Verba de nomeação de tutores e curadores; verba de nomeação de testamenteiros: ex.... que para seus testamenteiros nomeia seus amigos $\mathrm{F}$ e F., para servirem na ordem indicada um na falta do outro...

D. Encerramento:

a) Declaração do tabellião que rogado para a escriptura do testamento confirma ser esta a vontade do testador: ex... E por este modo disse elle testador havia por feita sua disposição de ultima vontade, que queria valesse como testamento, revogando por ella todas as outras anteriormente feitas...

b) Leitura perante elle e cinco testemunhas: ...ex. e depois de lhe ser lida por mim tabellião... (ou depois de ser lido por elle testador...) 
c) Determinação da assistencia de um acto e contexto nome e identidade de cinco testemunhas: ex... em presença das testemunhas F F. F F F., que assistiram ao acto, desde 0 principio até o fim, sendo para isso especialmente rogadas, foi por elle testador confirmada.

d) Resalva de emendas, entrelinhas, rasuras e do mais que duvida faça: ex. como nas outras escripturas.

e) Authenticação, subscripção e assignatura do tabellião: ex... Eu F., tabellião a escrevi e assigno. F. de tal nome por extenso do tabellião.

f) Assignatura do testador, si souber e puder escrever; ou si não souber ou não puder escrever assignatura de uma das cinco testemunhas; por seu mandado ou rogo, declarando essa testemunha, por este não saber (ou não poder) escrever."

g) Assignatura das cinco testemunhas.

Depois do Codigo civil, art. 1651, qualquer pessoa capaz de testar poderá, mediante escripto particular seu, datado e assignado, fazer disposições especiaes sobre seu enterro, sobre esmolas de pouca monta a certas e determinadas pessoas, ou indeterminadamente aos pobres de certo logar, assim como legar moveis, roupas ou joias não muito valiosas, de seu uso pessoal. Portanto, para o codicillo, não ha mais necessidade de escriptura publica nem se exige a assignatura de quatro testemunhas, como as antigas Ordenações. L. IV, tit. 86, pric. e $\oint \oint 1$ e 2.

As doações causa mortis, devem ter em regra as mesmas solemnidades do testamento. 


\section{Instrumentos publicos}

A locução instrumento publico, além do sentido lato, em que a tomamos no $\S 22$, tem um sentido restricto especial, na technica do fôro extra-judicial. Chama-se instrumento publico, neste sentido technico o instrumento que o tabellião póde lavrar fóra do Livro de Notas. Quanto a esses instrumentos nada de novo creou o nosso Codigo Civil ; basta notar, por exemplo, que em relação ao instrumento de approvação do testamento cerrado, o art. 1638, enumera todas as cautelas e formalidades com o mesmo rigor da Ord. L. IV, tit. $80 \$ \S 1$ e 2 . O Codigo usa da locução-instrumento publico-sem usar da locução escriptura publica; mas, nem por isso torna ineficaz a pratica attestada pela Ord. L. I, tit. 78 , pela qual a escriptura, que era o instrumento originariamente ou protocolarmente lavrado no livro de notas, se distingue do instrumento lavrado fóra do livro de Notas.

Actualmente lavram-se fóra das notas somente as approvações de testamentos e os protestos de letras e titulos semelhantes. As procurações que antigamente eram lavradas fóra das Notas, passaram a ser lavradas nas Notas ou em livros impressos, ex-vi do disposto no art. $98 \$ 1$ do Dec. 5737 de 2 de Setembro de 1874, os instrumentos de posse cahiram em desuso, tendo sido substituidos quanto a transmissão inter vivos, pela transcripção no Registro Geral, e, quanto ás transmissões calisa mortis, pela posse civil do Alvará de 9 de Novembro de 1754, sendo os mais casos possessorios remediados por posses judiciaes; as cautelas e formalidades do protesto de letras estão actualmente reguladas pela Lei n. 2044 de 31 de Dezembro de 1908, arts. 28 a 35 . Enumeremos as cautelas de alguns instrumentos.

Instrumento de approvação do testamento cerrado. Cautelas do Codigo Civil, arts. 1638 a 1644. Deve delle constar: 
1) Que o tabellião, rogado para approvação, comece a lavrar o instrumento immediatamente no fim do testamento; mas, não havendo logar na ultima folha escripta do testamento para nella começar o instrumento, 0 tabellião ponha nessa folha o signal publico, e assim o declare no instrumento.

2) O instrumento deve conter tres partes: introducção, confirmação e encerramento:

A. Introducção:

a) Formula preambular;

b) Anno, mez e dia,

c) Estado, cidade ou villa, cartorio ou casa.

d) Declaração de que 0 tabellião foi rogado pelo testador para a approvação.

e) Presença, reconhecimento da identidade e da sanidade mental do testador.

f) Presença, nomes e reconhecimento da identidade das cinco testemunhas.

B. Confirmação:

a) Entrega da cedula testamentaria pelo proprio testador ao tabellião, em presença das cinco testemunhas dizendo o proprio testador ser este $o$ seu testamento;

b) Recebimento da cedula testamentaria pelo proprio tabellião; verifica- 
ção sem leitura da cedula pelo proprio tabellião, de não haver borrão, riscadura, entrelinha ou cousa que duvida faça,

c) Pergunta do tabellião ao testador "si esse é o seu testamento e si o ha por bom, firme e valioso;

d) Resposta do testador ao tabellião "que esse é o seu testamento e que 0 ha por seu, bom e firme e que quer que o approve",

e) Declaração da approvação;

f) Presença, nomes e assistencia, em um acto e contexto, desde o principio até o fim das referidas cinco testemunhas.

C. Encerramento:

a) Leitura do instrumento perante 0 testador e as cinco testemunhas $\mathrm{e}$ declaração de conformidade;

b) Subscripção do tabellião e assignatura do mesmo em publico e razo.

c) Assignatura do testador, si souber e puder escrever, si não souber escrever, assignatura de uma das cinco testemunhas por seu mandado e rogo, declarando essa testemunha numeraria ao pé de sua assignatura (a rogo) (ou por mandado) do testador por elle não saber (ou não poder) escrever.

d) Assignatura das cinco testemunhas.

3) Assignado o instrumento, o tabellião deve dobral-o, cozel-o, collocar pingos de lacre aos lados, e depois, 
na face exterior que serve de involucro, escreverá o seguinte rotulo: "Testamento de F de Tal, approvado por mim tabellião $F$ de Tal, no dia tal do mez tal do anno...; cosido com tantos pontos de linha de tal côr e fechado com tantos pingos de lacre de tal côr. Era ut supra. O tabellião F..."

Formula:

Saibam quantos este instrumento virem que, no anno do Nascimento de Nosso Senhor Jesus Christo aos... aos... dias do mez de..., nesta cidade de... rua... casa de morada de F., onde eu tabellião a seu rogo fui vindo, sendo ali perante o dito $F$., doente de cama (ou são), mas a meu ver, em perfeito Juizo, o qual reconheço pelo proprio, do que dou fé; e sendo tambem ahi presentes as testemunhas abaixo nomeadas e assignadas, perante ellas o dito F. me entregou este papel, que disse ser 0 seu testamento (escripto e assignado por elle testador, ou apenas escripto, ou escripto por outros assignado por elle), e qual papel eu acceitei, achei com effeito ser o testamento delle testador, escripto em folhas, que vi mas não li; e não achando em todo elle borrão, riscadura, entrelinha ou cousa que duvida faça perguntei a elle testador si este é o seu testamento e si o ha por bom, firme e valioso, ao que elle respondeu, em pre- 
sença das mesmas cinco testemunhas abaixo nomeadas e assignadas, que é este o testamento que elle testador ha por bom, firme e que queira que eu tabellião lh'o approvasse, o que fiz em seguida, com todas as solemnidades legaes, em presença das testemunhas $F \quad F \quad F$ $F F$., residentes em... de mim conhecidas, as quaes assistiram o acto desde o principio até o fim e assignam com o testador depois de a todos ser lido e achado conforme este instrumenio, do que dou fé. $E u$ F Tabellião, o escrevi e assigno em publico e raso (Segue-se o signal publico e as assignaturas)

- Instrumento de protesto de letras e titulos semehantes:

A. Apontamento:

a) A letra que tiver de ser protestada, por falta de acceîe ou de pagamento, deve ser levada ao tabellião (ou ao official privativo) no primeiro dia util que se seguir ao da recusa do acceite ou ao do vencimento (Dec. n. 2044 de 31 de Dezembro de 1908, art. 28);

b) O official, perante quem se intentar o protesto, immediatamente tomará apontamento della em livro que é obrigado a ter, e a registrará do seguinte modo: "Protesto de uma 
letra apresentada ás... horas do dia... do mez de... de 19... Rs. (transcreve toda a letra mencionando o que nella se achar escripto, inclusive os sellos, terminando) $\mathrm{Eu}, \mathrm{F}$ tabellião (ou official privativo) 0 escrevi e assigno. Assignatura do official.

c) No alto da letra ou titulo o official averbará a folha do livro ou Protocollo em que a letra ou titulo está apontada, com a data de sua apresentação assim: "Apontada a fls... do livro competente, as ...horas do dia... do mez... do anno. O tabellião. ou social $\mathrm{F}$

d) Si o sacado ou acceitante está no logar e é contrecido, o tabellião ou official dentro de tres dias, lhe dirigirá uma carta de notificação communicando o apontamento e requisitando resposta com as razões porque não acceita ou não paga, nestes termos: "Illmo. Sr... Participo a V S. que em meu cartorio existe uma letra (ou titulo) da quantia de ...\$..., saccada por $F$ contra $V$ S., para ser protestada por falta de acceite (ou saccada por $F$ acceita por V S. para ser protestada por falta de pagamento), o que notifica a V S. para acceital-a, pagal-a, ou dar as razões porque não o faz. Data. $\mathrm{O}$ Off. F

e) Si o sacado é desconnecido ou não fôr encontrado, o tabellião ou official 
o notificará por edital, affixado em logar do estylo, e o publicará pela imprensa (Decr. 2044, art. 19, IV) Igual notificação deve ser feita aos outros responsaveis. O edital será assim redigido: "F., tabellião ou official privativo, etc. Faço saber que em meu cartorio existe uma letra de cambio (ou titulo) na importancia de ..., para ser protestada por falta de pagamento (ou de acceite) saccada por $F$ (ou saccada e endossada por $F$ ) contra $F$ e endossada por $F$., e ignorando-se a residencia do acceitante (ou acceitante e endossante) notifico-o para acceital-a ou pagal-a ou para dar as razões porque o não faz, ficando desde já intimado do respectivo protesto. Data. O Official. F

f) No fim de tres dias, caso não fôr acceita ou paga a letra ou titulo, será lavrado o instrumento de protesto.

B. Instrumento de protesto. Este instrumento deve conter quatro partes: introducção, declaração da notificação, protestos e encerramentos. (Decr. 2044, art. 29)

1) Introducção:

a) Formula preambular;

b) Anno, mez e dia;

c) Estado, cidade e cartorio;

d) Nome do portador ou apresentante

e) Copia do apontamento da letra ou titulo apresentado; 
2) Declaração da notificação:

a) Determinação do modo da notificação, si pessoal ou por edital;

b) Copia da resposta dos notificados ou a declaração da falta de resposta.

c) a indicação dos intervenientes voluntarios das firmas por elle honradas.

3) Protesî: :

a) Declaração de que foi communicada ao portador ou apresentante a resposta dos notificados ou a falta della;

b) a acquiescencia do portador ao acceite por honra;

c) Protesto de haver do saccador da letra ou titulo, ou de quem de direito, toda a importancia devida e custas, na forma do costume.

C. Encerramento:

a) Declaração do pedido de instrumento;

b) Assignatura do tabellião ou official com o seu signal publico.

Instrumentos particulares

Os praxistas dividem o. instrumento particular nas especies cedulas, syngraphos, chirographos, contas, recibos, cartas e livros.

Cedula, applicava-se antigamente aos insirumentos particulares destinados aos actos que exigem maior presteza e ás minutas, isto é, aos instrumentos feitos pelo tabellioni romano, emquanto não eram in mundum recepta subscrip- 
tionibusque paríium confirmata (Cod. de Fid. instru. VI, $21,17)$, essa palavra agora applica-se aos testamentos e codicillos cerrados, aos testamentos olographos, ás procurações, ás letras de cambio, ás acções de companhias anonymas, ás apolices, e tambem em geral aos instrumentos particulares que costumam ser impressos. (1)

Syngrapho, tambem de formação grega syn, com, juntamente e grapho escrever, é o instrumento particular assignados por outorgantes e outorgados, por credor e devedor: escriptos syngraphicos são por exemplo, os instrumentos particulares de contractos (Cod. Civ. art. 135), os estatutos de sociedades, etc.

Chirographo, tambem do grego keir, mão, e grapho escrever, é o instrumento particular de divida, feito e assignado, ou apenas assignado pelo devedor: e, no sentido lato, chirographo é todo o instrumento de divida escripto a mão, porem, em um sentido restricto, considera-se chirographaria apenas a divida não garantida por hypotheca, antichrese, penhor, e a que não representa guarda ou deposito, despezas feitas, salarios, honorarios ou qualquer outra obrigação privilegiada.

Conta é a classificação qualitativa e quantitativa das verbas do debito ou das verbas do debito e credito.

Recibo é a declaração daquelle que affirma ter recebido, por conta ou saldo, quantia ou qualquer outra cousa fungivel ou não fungivel.

Carta ou epistola é o instrumento particular dirigido a alguem que está ausente ou se considera como tal.

Livros são aquelles em que alguem escriptura o que dá e o que recebe, deve e haver, assim como aquelles em que os particulares assentam os seus factos e as suas contas.

Entre os documentos particulares ha alguns, taes como

(1) Scriptura privata dicitur illa quae non fit á publicis personis, nec per se habet authoritatem, nisi eam adversus agnosticat, aut per comparationem ad aliam escripturam authenticam, sive per subscriptionem partis, vel testium certificetur. 
a letra de cambio, o conhecimento de frete, a apolice de seguro, etc., para os quaes a lei exige forma especial; mas, as outras obrigações convencionaes de qualquer valôr, são provadas por instrumento particular, feito e assignado, ou somente assignado por quem esteja na disposição e administração livre de seus bens, sendo subscripto por duas testemunhas (Cod. Civil, art. 135) Dec. n. 79 de 1892 Dec. n. 973 de 1903.

A lei não exige forma especial para os instrumentos particulares, mas exige que sejam escriptos em lingua nacional, sendo os redigidos em lingua extrangeira, para terem effeitos legaes no paiz, vertidos para o portuguez (art. 140 do Cod. Civ.) "Assim tambem não devem ter emenda e rasuras em lugar substancial e suspeito. (Accordão do Trib. de Justiça de 18 de Março de 1903, S. P. Judic. Vol. 17 pag. 389) Devem satisfazer as exigencias fiscaes. Devem as firmas ser reconhecidas por tabellião, e, neste caso se não constar a data no instrumento, valerá a do reconhecimento. Assim como, se registrados no registro competente, para effeitos em relação a terceiros, valerá a data da transcripção para esse effeito (art. $1 \overline{3} 5$ do Cod. Civil) Entretanto, no Estado de São Paulo, nos termos do Regulamento Estadoal de 31 de Agosto de 1906, não farão prova sufficiente no processo judiciario e administrativo, não sendo de obrigações commerciaes, escriptos particulares que não estejam averbados ou registrados.

As declarações constantes de documentos assignados presumem-se verdadeiras em relação aos signatarios. (Cod. Civ. art. 131 \& unico)

Documentos particulares devem conter, em commum, a declaração da sua natureza, o valor, o lugar em que foi lavradio, nome e condição juridica das partes, nome das testemunhas, data da assignatura, reconhecimento de firma pelo rabellião e sello fiscal devido. 
Façamos agora uma subdivisão especifica com as respectivas cautelas e formulas:

Cedulas:

1) Cedula de testamento cerrado aberto Cautelas do Cod. Civil, art. 1638 ns. a XII)

a) Deve ser escripta pelo testador ou por outra pessoa a seu rogo, saiba ou não escrever deve 0 testador assignar se for por outro escripta; si não puder ou não souber o testador assignar, será assignada pela pessoa que lha escreveu.

b) A cedula deve conter, em regra, estas quatro partes:

1) Invocação: Ex. Em nome do Padre, do Filho, do Espirito Santo Amen. (Para os Catholicos)

2) Declarações pessoaes: ex. Este é o meu testamento 'e ultima vontade.

Declaro que sou natural de... filho legitimo de... (em summa declarar se quizer (religião, naturalidade, estado, filiação, filhos, etc.)

3) Disposições Ex. Institúo meu herdeiro a $F$ (Vide a ordem das disposições no $\S$, quanto ao testamento publico) .

4) Encerramento, com data e assignatura, na forma supra referida: ex: Este é o meu testamento que vae escripto por mim (ou que foi escripto por $F$ e por elle assignado a meu rogo, por não poder (ou não saber escrever) (ou que foi escripto por $F$ a meu rogo e por mim assignado) Data e assignatura. 
Esta cedula será entregue ao tabellião, em presença de cinco testemunhas, que lavrará nella o auto de approvação, devendo o testador declarar que aquelle é o seu testamento. Vide auto de approvação $\S 25$, referente ao testamento: publico.

2) Cedula de procuração (Cod. Civil, art. $1289 \$ \$ 1$ a 4$)$

a) Todas as pessoas maiores ou emancipadas, no gozo dos direitos civis, são aptas para dar procuração mediante instrumento particular do proprio punho. Os analphabetos só o podem fazer por instrumentos publicos. Concorrendo no mesmo instrumento mais outorgantes, será escripto por um e assignado por todos.

b) A cedula deve conter:

1) Estado, cidade ou circunscripção civii,

2) data ,

3) nome do outorgante;

4) individuação do outorgado;

5) objectivo da outorga;

6) Natureza, designação e extensão de poderes;

7) Reconhecimento de firma e letra no proprio instrumento. (Cod. Civil art. 1289 e Dec. 18.542 art. 161)

$B$. Cedulas de autorização (Cod. Civil, art. 132, arts. 233, 242, 235 e 154, I e Cod. Comm. arts. 1 III e IV e 28). Estas c£dulas são, em geral, dadas aos administradores, gerentes, agentes, assim como ás mulheres casadas e menores de 21 annos. A autorização para commer- 
ciar, porem deve ser dada por escriptura publica.

C. Acções de companhias anonymas e debentures, warrants, cheques, conhecimento de fretes, apolices de seguro, letras de cambio e da terra, notas promissorias, bilhetes de mercadorias, etc. Examinemol-as:

A. Acções de sociedades anonymas; estas cedulas devem conter (arts. 35 e 36 do Decr. n. 434 de 4 de Junho de 1891)

a) o numero de ordem;

b) o valor que cada uma representa;

c) a designação ou denominação da sociedade;

d) os direitos que conferem aos dividendos e capitaes;

e) a data da constituição da Sociedade e da publicação dos actos constituivos;

f) a assignatura pelo menos de dois administradores;

As acções transferiveis por endosso e ao portador, alem dessas declarações devem conter.

g) a somma total do Capital subscripto, com especificação da parte em dinheiro da parte em bens, cousas e direitos;

h) o numero de acções em que se divide o capital,

i) a duração da sociedade;

j) o dia e o logar da reunião annual da assenibléa geral; 
B. Debentures. Estas cedulas, alem das cautelas proprias dos titulos dessa natureza, devem conter (Decr. n. 434 de 4 de Junho de 1891, art. $44 \$$ unico):

a) a serie das obrigações,

b) o numero de ordem,

c) a somma do emprestimo a cuja serie pertencer.

As transferencias das acções de sociedades anonymas, estão sujeitas ao sello proporcional.

C. Conhecimento de deposito e warrants.

Cada uma dessas cedulas, além da sua designação particular, deve conter (art. 15 do Decreto n. 1102 de 21 de Novembro de 1903):

a) a clausula - a ordem;

b) a denominação da empreza do armazem geral e sua séde,

c) o logar e prazo do deposito;

d) o nome, profissão e domicilio do depositante ou de terceiro por este indicado;

e) a natureza e quantidade das mercadorias em deposito, designadas pelos nomes mais usados no commercio, seu peso, o estado dos envoltorios e todas as marcas e indicações proprias para estabelecerem a sua identidade.

f) a qualidade de mercadorias, tratando-se de mercadorias de uma mesma natureza e qualidade, já existente no armazem, 
g) a indicação do segurador da mercadoria e o valôr do seguro;

h) a declaração dos impostos e direitos fiscaes, dos encargos começaram a correr as armazenagens;

i) a data da emissão dos titulos e a assignatura da empreza ou pessoa habilitada por esta,

j) o sello proporcional.

$D$. Cheques. São as seguintes as cautelas (Dec. n. 2591 de 7 de Agosto de 1912, art. 2) :

a) a denominação-cheque - ou outra qualquer equivalente, se for escripta em lingua extrangeira;

b) indicação em cifra e por extenso da somma a pagar;

c) data, comprehendendo o logar, dia, mez e anno da emissão, sendo dia e mez por extenso;

d) assignatura do emittente;

e) nome da firma social ou pessoa que deve pagar;

f) indicação do logar onde o pagamento deve ser feito;

g) o sello fixo.

$E$. Conhecimento de fretes. (Estas cedulas devem conter (art. 575 do Cod. Commercial) :

a) a data, 
b) o nome do capitão, o do carregador e consignatario (podendo omittirse o nome deste, se for a ordem) e o nome e porte do navio;

c) a qualidade e a quantidade dos objectos da carga, suas marcas e numeros, annotados á margem,

d) o logar da partida e o do destino, com declaração das escalas, havendo-as,

e) o preço do frete e primagem, se esta for estipulada, e o logar e forma de pagamento;

f) a assignatura do capitão e do carregador;

$F$ Apolices de seguros maritimos (Cod. comm. art. 667), devem conter:

a) o nome, o domicilio do segurador e do segurado, declarando se segura por sua conta ou por conta de terceiro, cujo nome póde omittir-se; omitindo-se o nome do segurado o terceiro que faz o seguro em seu nome, fica pessoal e solidariamente responsavel. Em nenhum caso póde ser concedida ao portador;

b) o nome, classe e bandeira do navio e o nome do capitão, salvo não tendo

o segurado certeza do navio;

c) a natureza e qualidade do objecto seguro, ou o seu valôr fixo ou estimado;

d) o logar onde as mercadorias foram, deviam ou devam ser carregadas. 
$e$ ) os portos ou ancouradouros onde o navio deve carregar ou descarregar e aquelles em que deve tocar por escalas;

f) o porto donde o navio partiu, devia ou deva partir, e a epocha ou partida, quando esta houver sido positivamente ajustada,

g) menção especial de todos os riscos que o segurador toma sobre si,

h) o tempo é o logar em que os riscos devem começar a correr e acabar;

i) o premio do seguro, e o logar, epocha e forma de pagamento;

j) o tempo, logar e forma do pagamento no caso de sinistro:

$k$ ) declaração de que as partes se sujeitam á decisão arbitral quando haja contestação, se ellas assim 0 accordarem;

l) a data do dia em que se concluiu o contracto, com declaração se antes ou depois de meio-dia,

$m$ ) demais condições em que as partes convenham,

n) assignatura dos seguradores;

$G$. Letra de cambio; nota promissoria (Decreto n. 2044 de 31 de Dezembro de 1908 , arts. 1 e segs.)

A letra de cambio deve conter:

a) a denominação - letra de cambio - ou a equivalente na lingua extrangeira em que fôr emittida; 
b) a somma de dinheiro a pagar e a especie de moeda;

c) o nome da pessoa que deve pagal-a, esta indicação póde ser inserida abaixo do contexto;

d) o nome da pessoa a quem deve ser paga. A letra póde ser ao portador e tambem póde ser emittida por ordem e conta de terceiro;

e) a assignatura do proprio punho do sacador ou mandatario especial. A assignatura deve ser firmada abaixo. do contexto,

f) assignatura do acceitante no anverso da letra;

g) assignatura do avalista no verso ou anverso da letra (se houver);

h) assignatura do endossante (se houver) no verso da letra,

i) sello proporcional.

Nota promissoria, deve conter.

a) a denominação - nota promissoria ou termo correspondente na lingua em que fôr emittida;

b) a somma de dinheiro a pagar;

c) o nome da pessoa a quem deve ser paga;

d) a assignatura do proprio punho do emittente ou do mandatario especial;

e) o sello proporcional.

H. Apolices de seguros terrestres. Subdividem-se em seguros sobre bens e seguros de vida. Não podem ser ao portador (Cod. Civ. art. 1447). 
Estas cedulas devem conter:

a) o nome do segurador, do segurado. e o do seu representante, se houver. ou do terceiro em cujo nome se faz o seguro se são nominativas,

b) o começo e fim dos riscos, por anno, mez, dia e hora. Se não se estipularem essas clausulas, contar-se-á o prazo de accordo com o art. 125 do C. Civil ;

c) os riscos assumidos;

d) o valor do objecto seguro,

e) o premio devido ou pago pelo segurado;

f) quaesquer outras estipulações que no contracto se firmarem;

g) a assignatura do segurador, ou alguem com poderes para isso;

h) o sello proporcional

J. Bilhetes de mercadorias (Dec. n. 370 de 2 de Maio de 1890 art. 379). Esses bilhetes devem conter:

a) a data;

b) a qualidade das mercadorias consignadas;

d) A epocha em que esta deve fazer-se;

e) o valor como nas letras de cambio,

f) O sello proporcional.

Syngraphos - São os instrumentos particulares, onde intervêm duas ou mais pessoas que se obrigam a dar, fazer, ou não fazer alguma cousa. São assignados por 
outorgados, pelo crecior e devedor. O termo é de formação grega, composto de syn, com, juntamente, e grapho, escrever.

Escriptos syngraphicos, são, por exemplo, os instrumentos particulares dos contractos, os estatutos de sociedades $€$ em geral todas as obrigações convencionaes de ordem economica (Clovis Bevilaqua. C. Civil Comm. pg. 427)

Estes instrumentos devem ser feitos e assignados ou somente assignados por todas as pessoas que estiverem na livre disposição e administração de seus bens e subscriptos por duas testemunhas, salvo os casos em que o instrumento publico é da substancia do acto.

Fazem prova entre as pessoas que os assignam (art. 131 do Cod. Civil). Mas, para valerem contra terceiros, devem ser transcriptos no Registro Publico nos termos do art. 135 do Cod. Civil e na forma do Dec. n. 4775 de 1903. As certidões de registro inêgral desses titulos terão o mesmo valor probante dos originaes, nos termos do art. 138 do C. Civil, resalvado o incidente de falsidade, opportunamente levantado em juizo.

O Codigo civil não determina formalidades especiaes para os instrumentos particulares em geral. Exige a assignatura das partes e a subscripção de duas testemunhas.

O Decr. 4775 cit. art. 30, 31, dispõe que o registro integral dos documentos consistirá na transcripção completa, com a mesma ortographía e pontuação, referencia ás entrelinhas ou quaesquer accrescimos, alterações, defeitos ou vicios que tiver o original apresentado, e bem assim dus seus caracieristicos exteriores e formalidades legaes, qualidade e importancia do sello. O registro resumido consistirá na declaração da natureza do titulo, documento ou papel, valor, prazo, logar em que tenha sido lavrado, nome e condição juridica das partes, nomes das testemunhas, data da assignatura e do reconhecimento da firma pelo tabellião si o houver, importancia e qualidade do sello pago. 
Dahi a conveniencia de ser observada nos documentos de contractos por escripto particular a seguinte ordem, como util cautela:
a) nominação
b) determinação do objecto
c) determinação do accordo
d) assignatura das partes e de duas testemunhas
e) sello fiscal devido.

As minutas dos contractos, quando assignadas pelas partes contra as quaes se produzem, servem de prova no Juizo Commercial, ou por si sós, ou acompanhadas de outras provas (Reg. 737, de 1850 art. 152 \$5)

A lei exige em alguns casos que certos instrumentos particulares sejam lavrados em duplicata ou porque obrigações reciprocas nellas se declaram ou porque encerram obrigações de ordem geral. Exemplo da primeira hypothese, é o art. 771 do Codigo Civil exigindo que os contractos de penhor por instrumento particular, sejam firmados pelas partes e lavrados em duplicata, ficando um exemplar com cada um dos contrahentes, qualquer dos quaes póde leval-o a transcripção; e da segunda é o art. 51 do Dec. n. 370 de 1890, exigindo no Registro de immoveis, se o titulo for de natureza particular, sua apresentação ao mencs em dupiicata, ficando um dos exemplares archivado no Registro e sendo o outro ou os demais devolvidos após o registro.

Os contractos de qualquer sociedade commercial devem ser registrados para valerem entre os socios e contra terceiros e devem conter (art. 302 do Cod. Comm.)

a) os nomes, naturalidades e domicilios dos socios;

b) sendo a sociedade com firma, a firma por que a sociedade ha de ser conhecida 
c) os nomes dos socios que pódem usar da firma social ou gerir em nome da sociedade; na falta desta declaração entendese que todos os socios podem usar da firma social e gerir em nome da sociedade;

d) designação especifica do objecto da sociedade, da quota com que cada um dos socios entra para o capital e da parte que ha de ter nos lucros e nas perdas;

e) a forma da nomeação dos arbitros para juizes das duvidas sociaes:

f) não sendo a sociedade por tempo indeterminado, as epochas em que ha de começar e acabar e a forma de sua liquidação e partilha,

g) todas as condições e clausulas necessarias para determinarem com precisão os direitos e obrigações dos socios entre si e para com terceiros;

h) o sello proporcional.

Nas sociedades anonymas a acta da reunião em que fôr deliberada a constituição da sociedade, deve ser assig.. nada por todos os socios presentes e será lavrada em duplicata, ficando um dos exemplares em poder da sociedade e tendo o outro o destino legal (Dec. n. 434 de 1891, art. 76)

Chirographo - é o instrumento particular de divida feito e assignado ou apenas assignado pelo devedor. Deriva-se do grego-keir, mão, e grapho, escrever.

Num sentido lato, chirographo é todo o instrumento de divida escripto a mão. Consta geralmente em declaração de divida e promessa de pagamento. Deve conter (art. 135 do Cod. Civil) : 
a) a letra e assignatura do devedor, ou somente a assignatura,

b) a data e o logar onde foi feito;

c) a assignatura de duas testemunhas;

d) o sello proporcional.

Quem o firma deve estar na administração livre de seus bens. A formula costuma ser enunciada nestes termos:

"Devo que pagarei ao sr.... a importancia de... que delle recebi por emprestimo, obrigando-me a pagar-lhe egual quantia e mais os juros de ....\% no prazo de... mezes"

Em sentido restricto a expressão credito chirograpinario designa o que não é garantido por hypotheca, antichrese ou penhor, ou em geral, o que não está especificado entre as preferencias e privilegios do art. 1557 e segs. do Cod. Civil, assim como os arts. 91 e segs., da lei n. 2024 de 1908 e nos arts. 619 e 624 do Reg. 737

Os creditos chirographarios occupam o ultimo logar no concurso de credores.

O credor chirographario que recebeu do devedor insolvente o pagamento da divida ainda não vencida, ficará obrigado a repôr, em proveito do acervo sobre que se tenha de effectuar o concurso de credores, aquillo que recebeu. (art. 110 do Codigo Civil)

Recibos. - Recibos por conta. Recibos por saldo:

Ambos devem conter: (art. 940 do Cod. Civil)
a) o valor recebido;
b) a especie da divida quitada,
c) a especificação por conta ou saldo;
d) o nome do devedor ou de quem por este pagou;


e) o tempo e logar do pagamento;

f) a assignatura do credor ou seu representante;

g) o sello fixo.

Se o pagamento for por quotas periodicas, a quitação da ultima estabelece, até prova em contrario, a presumpção de estarem solvidas as anteriores, (art. 943)

Dr. Jỗo Mendes de Almeida Juñior. 